\title{
Effects of Drought Stress and Storage on the Metabolite and Hormone Contents of Potato Tubers Expressing the Yeast Trehalose-6-phosphate Synthase 1 Gene
}

\author{
Zsófia Juhász ${ }^{1}$, Dirk Balmer ${ }^{2}$, Anita Sós-Hegedüs ${ }^{1}$, Armelle Vallat ${ }^{3}$, Brigitte Mauch-Mani ${ }^{2} \&$ Zsófia Bánfalvi ${ }^{1}$ \\ ${ }^{1}$ NARIC Agricultural Biotechnology Institute, Gödöllő, Hungary \\ ${ }^{2}$ Faculty of Sciences, University of Neuchâtel, Neuchâtel, Switzerland \\ ${ }^{3}$ Chemical Analytical Service of the University of Neuchâtel, Neuchâtel, Switzerland \\ Correspondence: Zsófia Bánfalvi, NARIC Agricultural Biotechnology Institute, P.O. Box 411, Gödöllö, Hungary. \\ Tel: 36-28-526-153. E-mail: banfalvi@abc.hu
}

Received: February 8, 2014 Accepted: March 11, 2014 Online Published: April 15, 2014

doi:10.5539/jas.v6n5p142 URL: http://dx.doi.org/10.5539/jas.v6n5p142

\begin{abstract}
Comparative studies on the tuber yield and quality of commercial potato cultivars were conducted. White Lady was the wild-type (WT) accession used, and transgenic lines in this background expressing the yeast trehalose-6-phosphate synthase 1 (TPS1) gene were analysed. The plants were grown in a greenhouse under well-watered and drought stress conditions, and the metabolite and hormone contents of freshly harvested and stored tubers were tested. Periodic drought resulted in an average 50\% yield loss in WT and a $30 \%$ yield loss in TPS1 plants. However, the average tuber mass remained higher in WT than in TPS1 plants. Stress elevated the abscisic acid, proline, asparagine, and phenylalanine levels and significantly affected the levels of an additional 12 compounds in tubers. In contrast to abscisic acid, the salicylic acid levels in stressed tubers were reduced. In general, storage and stress had similar effects on the metabolite and hormone concentrations in both WT and TPS1 tubers. Interestingly, storage increased the mannose, phenylalanine, and abscisic acid concentrations and decreased the salicylic acid concentrations only in the tubers of well-watered plants. TPS1 tubers had a longer dormancy period than WT tubers and exhibited alterations in the concentrations of 13 metabolites.
\end{abstract}

Keywords: drought stress, hormones, metabolic profiling, Solanum tuberosum L., sprouting, tuber

Abbreviations: ABA: abscisic acid, CK: cytokinin, ET: ethylene, GA: gibberellic acid, GC-MS: gas chromatography-mass spectrometry, JA: jasmonic acid, JA-ILE: jasmonic acid-isoleucine, IAA: indole-3-acetic acid, TPP: trehalose-6-phosphate phosphatase, TPS1: trehalose-6-phosphate synthase 1, SA: salicylic acid, UHPLC-MS/MS: ultra-high-pressure liquid chromatography-tandem mass spectrometry, WT: wild-type

\section{Introduction}

Drought is by far the most important environmental stress in agriculture, and improving crop yields under drought stress is a major goal of plant breeding. To date, various approaches have been used to produce drought-tolerant plants. One of the approaches is the engineering of transgenic cultivars expressing osmolyte biosynthesis genes (Cattivelli et al., 2008).

Drought-tolerant transgenic rice lines showing tissue-specific or stress-inducible accumulation of the osmolyte trehalose, which has no negative effects, have been isolated previously (Garg et al., 2002). Based on this work, an attempt to improve the drought tolerance of the potato cv. White Lady was made by increasing the level of trehalose via transformation with the yeast trehalose-6-phosphate synthase 1 (TPS1) gene driven by the promoter of the drought-inducible potato gene, StDS2 (Dóczi et al., 2002). Using a marker-free transformation method, two independent TPS1 transgenic potato lines, T1 and T2, were isolated. In contrast to the expected drought-induced expression, only very low, constitutive TPS1 expression was detected in the transgenic lines, likely because of chromosomal position effects. This expression pattern, however, was sufficient to alter the plants' drought responses. Detached leaves of the T1 and T2 plants showed an eight-hour delay in wilting compared to the non-transformed wild-type (WT) control. Potted T1 and T2 plants retained water for six days longer than WT plants and maintained high stomatal conductance as well as a satisfactory rate of net photosynthesis. Under 
optimal growth conditions, however, the transgenic plants grew more slowly, had a lower $\mathrm{CO}_{2}$ fixation rate, and exhibited a $35 \%$ reduction in stomatal density (Stiller et al., 2008). To understand the molecular basis of this phenomenon, the transcriptomes and metabolites of WT and TPS1 transgenic plants were compared using microarray analysis and gas chromatography-mass spectrometry (GC-MS). In total, 99 genes were differentially expressed in the mature source leaves of TPS1 transgenic plants compared with WT. Although the trehalose concentration did not change, the malate, inositol, and maltose levels were higher in the TPS1 leaves than in the WT leaves (Kondrák et al., 2011). Transcriptomic and metabolic profiling also revealed that the levels of several mRNAs and metabolites were altered in the leaves of drought-stressed plants. In total, 379 genes of known function showed at least a 2-fold expression change between genotypes, between stress conditions, or both. The majority of the genes with altered expression were implicated in photosynthesis and carbohydrate metabolism and were downregulated in both WT and TPS1 plants upon drought stress. The fructose, galactose, and glucose contents were increased and decreased in drought-stressed WT and TPS1 leaves, respectively, while the amounts of proline, inositol, and raffinose were highly increased in both WT and TPS1 leaves under drought conditions (Kondrák et al., 2012).

Leaf alterations can influence tuber development and quality. For example, the ectopic expression of the Arabidopsis phytochrome B gene, which encodes a photoreceptor in leaves, can increase tuber yield, and this effect is largely due to increased leaf stomatal conductance (Thiele et al., 1999). In contrast, drought stress induces stomatal closure, which limits photosynthesis and leads to reduced assimilate production and canopy growth, which in turn results in lower tuber yield and quality (Gregory \& Simmonds, 1992).

After they are produced, tubers undergo a period of dormancy, and the length of this dormancy period is under genetic and environmental control. Temperature, water availability, and photoperiods during growth and storage are important environmental factors that regulate sprouting behaviour. Although dormancy is defined as the absence of visible growth, dormant meristems are metabolically active, and several transcripts and proteins unique to either dormant or growing meristems have been identified (Bachem et al., 2000). Dormancy is also under hormonal regulation. Gibberellins (GAs) and cytokinins (CKs) are generally considered growth promoters, whereas abscisic acid (ABA) and ethylene (ET) are believed to inhibit sprout growth. Recently, it was shown that the reactivation of meristem activity and sprout growth requires both CK and GA and that free indole-3-acetic acid (IAA) might shorten dormancy by stimulating bud growth (S. Sonnewald \& U. Sonnewald, 2013). Tuber cells must be metabolically competent before plant hormones can exert their growth control. This was demonstrated by expressing the Escherichia coli OtsB gene, which encodes trehalose-6-phosphate phosphatase (TPP), in tubers, which was found to promote tuber sprouting (Debast et al., 2011). In contrast, the expression of an E. coli trehalose-6-phosphate synthase (OtsA) in potatoes resulted in a considerable delay in tuber sprouting (Lytovchenko et al., 2005; Debast et al., 2011).

Based on these findings, we investigated the metabolite and hormone compositions of tubers of potato plants expressing the yeast TPS1 gene. To examine environmental effects, the plants were grown under well-watered and drought stress conditions, and tubers were analysed shortly after harvest and after three months of storage at room temperature.

\section{Materials and Methods}

\subsection{Plant Materials and Growth Conditions}

The potato (Solanum tuberosum L.) cv. White Lady and the TPS1-expressing transgenic lines, T1 and T2 (Stiller et al., 2008), were vegetatively propagated from cuttings on RM medium (MS medium without vitamins) (Murashige \& Skoog, 1962) containing $2 \%(\mathrm{w} / \mathrm{v})$ sucrose at $24{ }^{\circ} \mathrm{C}$ with a photoperiod of $16 \mathrm{~h}$ of light $\left(170 \mu \mathrm{mol} \mathrm{m} \mathrm{m}^{-2} \mathrm{~s}^{-1}\right)$ and 8 $\mathrm{h}$ of darkness.

Six-week-old plants obtained by tissue culture were transferred into pots containing sterile A260 soil (Stender AG, Schermbeck, Germany; $1,000 \mathrm{~g} / \mathrm{pot}$ ) and grown under greenhouse conditions at $18-28^{\circ} \mathrm{C}$. The soil water content was determined gravimetrically (g of water per $\mathrm{g}$ of soil) at a depth of $5-7 \mathrm{~cm}$. Optimal growth conditions were provided by regular watering (70-80\% soil humidity). Pesticides and fungicides were applied when needed. Four weeks after planting, the plants were divided into two groups. Seven plants per line were continuously irrigated to maintain $70 \%$ soil moisture content, and eight plants per line were exposed to drought stress by withholding irrigation for 7-10 days while the water content of the soil decreased to $30 \%$. Seven dry cycles were created within a growing season. Between the dry cycles, the plants were irrigated with an optimal amount of water for one week. The tubers were harvested at full maturity four months after planting. The entire experiment was repeated twice. 


\subsection{Non-Targeted Analysis of Polar Metabolites}

The peeled tubers were chopped in an electric blender and ground into a fine powder in liquid nitrogen. Metabolite extraction was performed according to a previously published method (Schauer et al., 2005) by mixing $125 \mathrm{mg}$ of tuber powder with $700 \mu \mathrm{l}$ of methanol; $60 \mu \mathrm{l}$ of the internal standard $\left(0.2 \mathrm{mg} \mathrm{ml}^{-1}\right.$ ribitol in water) was subsequently added. The mixture was extracted by shaken at $1,000 \mathrm{rpm}$ for $15 \mathrm{~min}$ at $70^{\circ} \mathrm{C}$, and mixed vigorously with 1 volume of water. To separate the polar and non-polar metabolites, $375 \mu \mathrm{l}$ of chloroform was added, and the mixtures were vortexed. After centrifugation at 13,000 rpm for $15 \mathrm{~min}, 150 \mu \mathrm{l}$ from the upper methanol/water phase was removed and reduced to dryness in a vacuum. For methoxyamination, $40 \mu \mathrm{l}$ of methoxyamine hydrochloride (MEOX) dissolved in $20 \mathrm{mg} \mathrm{ml}^{-1}$ pyridine was added to the dried extract and agitated for $90 \mathrm{~min}$ at $37{ }^{\circ} \mathrm{C}$. $\mathrm{N}$-methyl-N-(trimethylsilyl) trifluoroacetamide (MSTFA) was used for derivatisation $\left(60 \mu 1,30 \mathrm{~min}, 37^{\circ} \mathrm{C}\right)$. The samples were analysed in the splitless mode in a quadrupole-type GC-MS system (Finnigan Trace/DSQ, Thermo Electron Corp., Austin, TX, USA) equipped with a $30 \mathrm{~m}$ capillary column (Rxi-5 ms, $0.25 \mathrm{~mm}$ ID, $0.25 \mu \mathrm{m}$ df, Restek, Bellefonte, PA, USA). Sample aliquots $(1 \mu \mathrm{l})$ were injected with a split ratio of $30 \mathrm{ml} \mathrm{min}^{-1}$ using the hot-needle technique. The injection temperature was $230{ }^{\circ} \mathrm{C}$, and the temperature of the interface and the ion source was set to $250{ }^{\circ} \mathrm{C}$. The carrier gas was helium, and a constant flow rate of $1 \mathrm{ml} \mathrm{min}^{-1}$ was used. The temperature program included $12.5 \mathrm{~min}$ of isothermal heating at $90^{\circ} \mathrm{C}$ for $2 \mathrm{~min}$, followed by a $5{ }^{\circ} \mathrm{C} \mathrm{min}^{-1}$ oven temperature ramp to $330{ }^{\circ} \mathrm{C}$. The system was temperature equilibrated for $2 \mathrm{~min}$ at $90{ }^{\circ} \mathrm{C}$ prior to the injection of the next sample. The detection was performed in the total ion chromatogram (TIC) positive mode. The identification and quantification of the 33 compounds listed in Table 1 were achieved using the NIST 11 mass spectral database. In addition, the sugars and amino acids presented in Figure 2 were identified based on comparisons of the retention times and mass spectra with those of standards analysed under identical conditions.

\subsection{Extraction and Assays of Trehalose-6-phosphate (T6P) and Trehalose by GC-MS}

T6P was extracted from tuber tissues using the method described by Lunn et al. (2006) with modifications. Aliquots ( $250 \mathrm{mg}$ fresh weight) of the frozen tuber powder were transferred to pre-cooled 2-ml Eppendorf tubes, vortexed with $500 \mu \mathrm{l}$ of ice-cold chloroform/methanol $(3: 7, \mathrm{v} / \mathrm{v})$, and incubated at $-20{ }^{\circ} \mathrm{C}$ for $2 \mathrm{~h}$ with occasional mixing. Water-soluble components, including T6P, were extracted from the chloroform phase by adding $400 \mu 1$ of water. After centrifugation at $13,000 \mathrm{rpm}$ for $4 \mathrm{~min}$ at $4{ }^{\circ} \mathrm{C}$, the aqueous-methanol phase was transferred to a $5-\mathrm{cm}$ Petri dish and maintained at $4{ }^{\circ} \mathrm{C}$. The extraction was repeated with $400 \mu \mathrm{l}$ of cold water, and the second extract was combined with the first extract. The methanol was evaporated in a laminar flow cabinet, and the aqueous solution was supplemented with water to $1 \mathrm{ml}$. High molecular mass components were removed from the samples by applying an Amicon Ultra-4 centrifugal filter device (Millipore) and centrifuging at $4,000 \mathrm{~g}$ for $20 \mathrm{~min}$ at $4{ }^{\circ} \mathrm{C}$. An aliquot $(100 \mu \mathrm{l})$ of the extract was dried with $20 \mu \mathrm{l}$ of ribitol $\left(20 \mathrm{mg} \mathrm{ml}^{-1}\right)$. Methoxyamination, derivatisation, and GC-MS analysis were carried out as described above for non-targeted metabolite analysis except that the detection was performed in the selected ion monitoring (SIM) positive mode. The selected ions had $\mathrm{m} / \mathrm{z}$ values of 271, 315, and 387. The T6P concentrations of the tubers were calculated using a standard (Sigma Cat. No. T4272).

Detection of trehalose was attempted in the tubers following the methods of Kim et al. (2012). The parameters of the GC-MS analysis were the same as those described above, and a standard (Sigma Cat. No. T5251) was used to identify the trehalose in the total ion chromatogram.

\subsection{Plant Hormone Quantification}

Hormones were quantified simultaneously in single samples using an optimised UHPLC-MS/MS analysis method as previously described (Glauser et al., 2014). Briefly, hormones were isolated from tissue samples (100 mg fresh weight) using a 99.5:0.5 (v/v) ethanol acetate:formic acid extraction solvent. During the extraction, an internal standard solution with isotopically labelled hormones was added to the samples. The hormones were quantified based on a calibration equation obtained by linear regression from a calibration curve for each analyte. The peak areas of the hormones measured in the samples were normalised to the internal standard before applying the calibration equation.

\subsection{RNA Isolation and Analysis}

Total RNA was extracted from leaves and tubers according to the method of Stiekema et al. (1988) and quantified using a NanoDrop spectrophotometer. DNaseI-treated total RNA $(2 \mu \mathrm{g})$ was reverse-transcribed with the High Capacity cDNA Reverse Transcription Kit (Applied Biosystems, Foster City, CA, USA). The obtained cDNAs were diluted 10-fold, and the RT-PCR assays were performed with TPS1-specific primers (5'-ATTCTGGATCGTTCA-3' and 5'-GATGAAATCGCAGACTTACA-3') and 18S rRNA primers (5'-GGG CAT TCG TAT TTC ATA GTC AGA G-3' and 5'-CGG TTC TTG ATT AAT GAA AAC ATC CT-3'). 


\subsection{Statistical Analysis}

Student's $t$ test was used to determine significant differences in the relative tuber number, yield, and T6P level at $P<0.05$ and $P<0.01$.

Using the SPSS software package (SPSS Inc., an IBM Company), one-way MANOVA was applied to determine differences $(P<0.05)$ between the metabolite compositions of independent groups (i.e., tubers of well-watered plants vs. stressed plants, fresh tubers vs. stored tubers, and WT tubers vs. TPS1 transgenic tubers).

\section{Results}

\subsection{Effects of Drought Stress on Yield and Tuber Dormancy}

WT control plants and the TPS1 transgenic lines T1 and T2 were grown under well-watered and periodic drought conditions in two independent experiments, as described in the Materials and Methods section. Under well-watered conditions, the number of tubers per plant and the total tuber biomass were reduced in both TPSI lines compared to the WT controls (Figure 1A \& 1B). The average tuber number per plant was similar in the two experiments (3.9 and 4.0 tubers per well-watered WT plant), although the average yield was quite different between the two experiments (11.8 $\mathrm{g}$ and $17.6 \mathrm{~g}$ of tubers per well-watered WT plant). However, both parameters were always lower in the TPS1 transgenic lines than in WT. Under well-watered conditions, the average reductions in yield were 60 and $50 \%$ for the T1 and T2 plants, respectively, compared to WT. Periodic drought caused an increase in the number but a reduction in the size of the WT tubers and, in general, resulted in a 50\% yield loss. Drought had a milder effect on the TPS1 transgenic plants and tubers; the increase in the number of tubers was less pronounced than the increase in WT, and the reduction in yield generally did not exceed $20-40 \%$ (Figure 1A \& 1B).

(A)

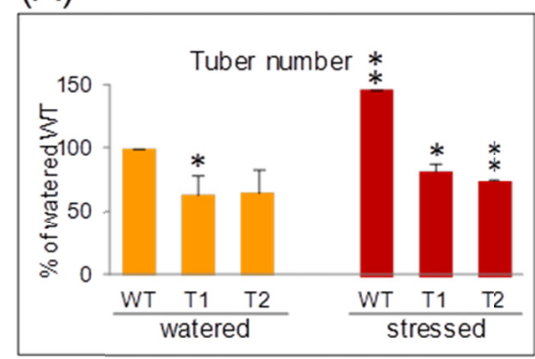

(B)

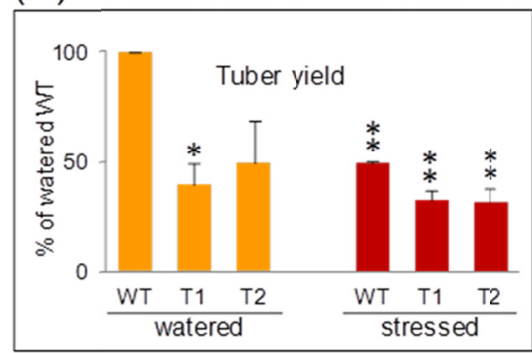

(C)

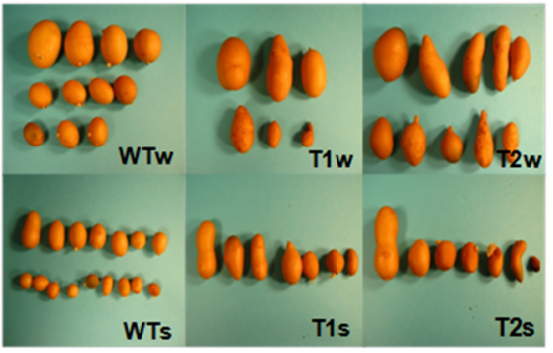

(D)

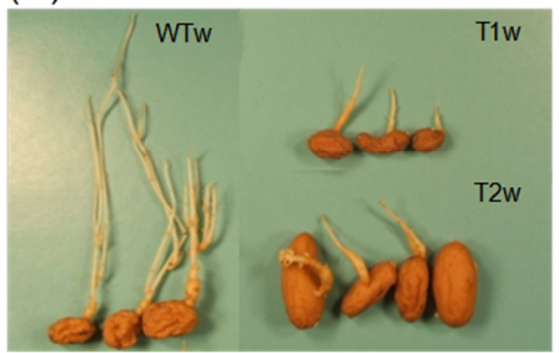

Figure 1. Tuber numbers and tuber yields of wild-type (WT) and TPS1 (T1 and T2) plants under well-watered (w) and drought-stress (s) conditions. (A) Relative tuber number per plant. (B) Relative tuber yield per plant. (C) Tubers at 12 weeks after harvest stored at room temperature in darkness. (D) Tubers at 6 months after harvest stored at room temperature in darkness. Bars and error bars represent the mean \pm SD from two independent experiments. In each experiment, the tubers were harvested from seven well-watered and eight stressed plants per line. The average numbers of tubers per well-watered WT plant in the two independent experiments were 3.9 and 4.0, while the tuber yields were $11.8 \mathrm{~g}$ and $17.6 \mathrm{~g}$. These values are considered $100 \%$ for comparisons with the other samples in the same experiments. ${ }^{*} P<0.05,{ }^{* *} P<0.01$ (Student's $t$ test)

The $\mathrm{T} 1$ and $\mathrm{T} 2$ tubers were longitudinal in shape, and the WT tubers were oval (Figure 1C). The tubers were stored at room temperature $\left(20-22^{\circ} \mathrm{C}\right)$ in the dark and were assessed visually on a weekly basis for sprouting. WT tubers started sprouting in a highly synchronised manner 12 weeks after harvest. In contrast, sprouting in the T1 and T2 
tubers was significantly delayed compared with sprouting in the WT. By week 12, only a few tubers had small sprouts, and full sprouting was achieved only at approximately 18 weeks after harvest. Sprout development was slow in the T1 and T2 plants compared to WT. After six months of storage, the sprouts on the T1 and T2 tubers were 1-5 cm in length, while those on the WT tubers reached 15-20 cm (Figure 1D).

The sprouting behaviour of well-watered plants did not differ substantially from that of drought-stressed plants in our experiments.

\subsection{Metabolite Content of Tubers}

The metabolite content of tubers was analysed by GC-MS. A total of 33 compounds, primarily including amino acids, organic acids, sugars, and sugar alcohols, were identified (Table 1). Significant changes induced by stress, storage, the combination of stress and storage, or the expression of TPS1 were detected for 28 metabolites (Figure $2 \&$ Supplementary Figure 1). The largest changes were detected in the concentrations of fructose, glucose, galactose, mannose, proline, asparagine, and phenylalanine (Figure 2). The tuber content of sucrose, which is the most abundant sugar in tubers, is also shown in Figure 2.
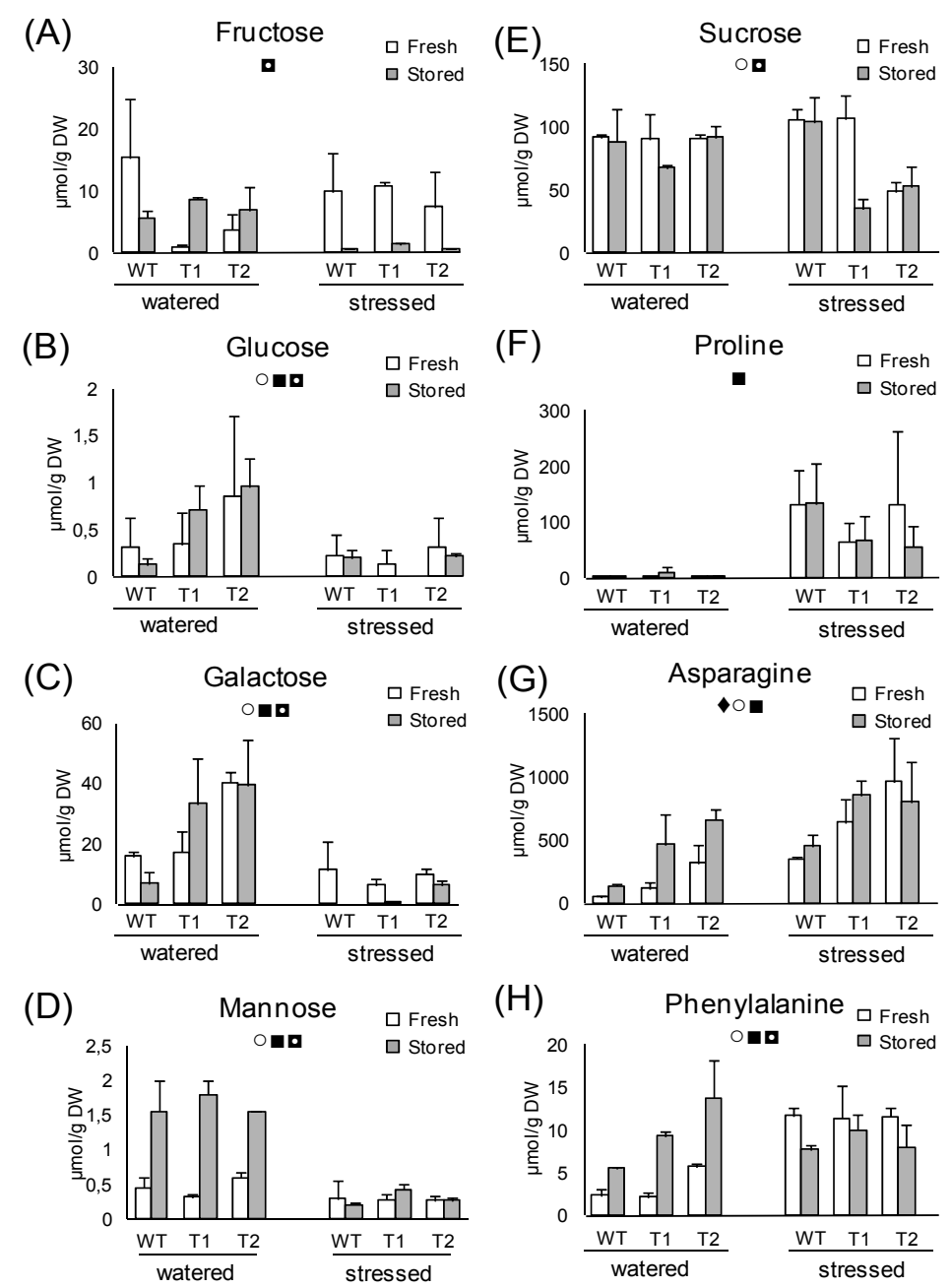

Figure 2. Metabolites detected by GC-MS. The bars and error bars represent the mean $\pm \mathrm{SD}$ of two groups of tubers derived from two independent experiments. In each experiment, the tubers were harvested from seven well-watered and eight stressed plants per line. Freshly harvested tubers and tubers stored for 12 weeks at room temperature in darkness were analysed. Tubers larger than $2 \mathrm{~cm}$ in diameter were selected, peeled, and grouped. The number of tubers per group was 6-13 and the tubers weighed 20-180 g. Significant differences (one-way MANOVA, $P<0.05$ ) between the tubers of well-watered and drought-stressed plants are indicated by $\mathbf{m}$, those between fresh and stored tubers are indicated by $\circ$, and those between WT and TPS1 tubers are indicated by Interactions between stress and storage are indicated by $\mathbf{0}$. WT, wild-type; T1 and T2, TPS1 lines; DW, dry weight 
Table 1. Compounds detected in tubers by non-targeted GC-MS analysis

\begin{tabular}{ll}
\hline Compound class & Metabolites \\
\hline Amino acid & $\begin{array}{l}\text { B-alanine, asparagine, aspartic acid, } \gamma \text {-aminobutyric acid (GABA), glutamic acid, } \\
\text { glutamine, glycine, isoleucine, phenylalanine, proline, serine, threonine, } \\
\text { tryptophan, 5-oxoproline } \\
\text { fructose, galactose, glucose, maltose, mannose, raffinose, sucrose } \\
\text { Sugar }\end{array}$ \\
Organic acid & galactinol, inositol, mannitol, sorbitol \\
Sugar alcohol & palmitic acid, stearic acid \\
Fatty acid & glucose-6-phosphate \\
Other &
\end{tabular}

Storage led to changes in the levels of 17 compounds (Supplementary Table 1), including the sugars glucose, galactose, mannose, and sucrose (Figure 2B-2E) and the amino acids asparagine and phenylalanine (Figures $2 \mathrm{G} \&$ $2 \mathrm{H}$ ). Stress affected the amounts of 14 compounds (Supplementary Table 1). The highest increases induced by drought were in the concentrations of proline, asparagine, and phenylalanine (Figure 2F-2H). The TPS1 transgene significantly influenced the amounts of 13 metabolites: asparagine (Figure 2G), B-alanine, aspartic acid, GABA, galactaric acid, glutamine, glycine, isocitric acid, mannitol, 5-oxoproline, serine, stearic acid, and threonine (Supplementary Table $1 \&$ Supplementary Figure 1). Similar to what was observed for asparagine (Figure 2G), higher concentrations of 11 metabolites were detected in transgenic tubers compared to WT tubers. In general, the metabolite contents of TPS1 transgenic tubers and WT tubers were similarly affected by storage.

\subsection{Hormone Content of Tubers}

The same set of tubers that were tested to determine their metabolite contents were also tested to determine their hormone contents using ultra-high-pressure liquid chromatography-tandem mass spectrometry (UHPLC-MS/MS). Our study focused on ABA, SA, and JA because of their roles in the mediation of stress responses (Acharya \& Assmann, 2009). IAA was also measured. As expected, the ABA concentration in tubers harvested from stressed plants was higher than that of tubers harvested from well-watered plants. Unexpectedly however, although the concentration of ABA increased upon storage in the tubers of well-watered plants, it remained at the same level in tubers of stressed plants (Figure 3A). The changes in SA showed an opposite trend. SA was present in higher amounts in the tubers of well-watered plants than in the tubers of stressed plants, and it decreased in the tubers of well-watered plants only upon storage (Figure 3B). JA and its active form JA-ILE were present in very low amounts in freshly harvested tubers, and their concentrations decreased over time (Figures 3C \& 3D). The IAA concentration was higher in tubers of TPS1 transgenic plants than in WT plants (Figure 3E).

\subsection{TPS1 Gene Expression and T6P Content in Tubers}

In the TPS1 transgenic lines T1 and T2, the transgene is expressed under the control of the promoter region of the $S$. tuberosum DS2 gene, which was shown to be activated by drought in an ABA-independent manner in leaves (Dóczi et al., 2002). Nevertheless, it was found that in the transgenic lines, TPS1 was expressed at a very low level in leaves, even under optimal growth conditions, and it was induced only moderately by drought (Stiller et al., 2008). TPS1 expression in tubers was not tested in previous experiments. Figure 4A shows that TPS1 was expressed in freshly harvested tubers of well-watered plants at a low level and increased slightly under drought stress. Figure 4A also shows that the amount of TPS1 mRNA decreased upon storage.

To assess whether transgene expression affects the T6P content in tubers, the T6P level was measured in samples from transgenic tubers and WT control tubers. As shown in Figure 4B, a significant difference $\left({ }^{*} P<0.01\right)$ was detected in only one transgenic sample compared with the freshly harvested, well-watered WT control. Nevertheless, the T6P level in the transgenic line was lower than that in WT; thus, it may reflect the heterogeneity of the tubers rather than the effect of TPS1 expression.

Plant cells contain a wide array of non-specific phosphatases; thus, T6P may be converted to trehalose without the simultaneous stimulation of TPP activity (Elbein et al., 2003). To test this hypothesis, we attempted to measure the trehalose concentrations of tubers by GC-MS. However, the tuber trehalose content was below the detection level $\left(<0.05 \mu \mathrm{mol} \mathrm{g}^{-1} \mathrm{DW}\right)$. 

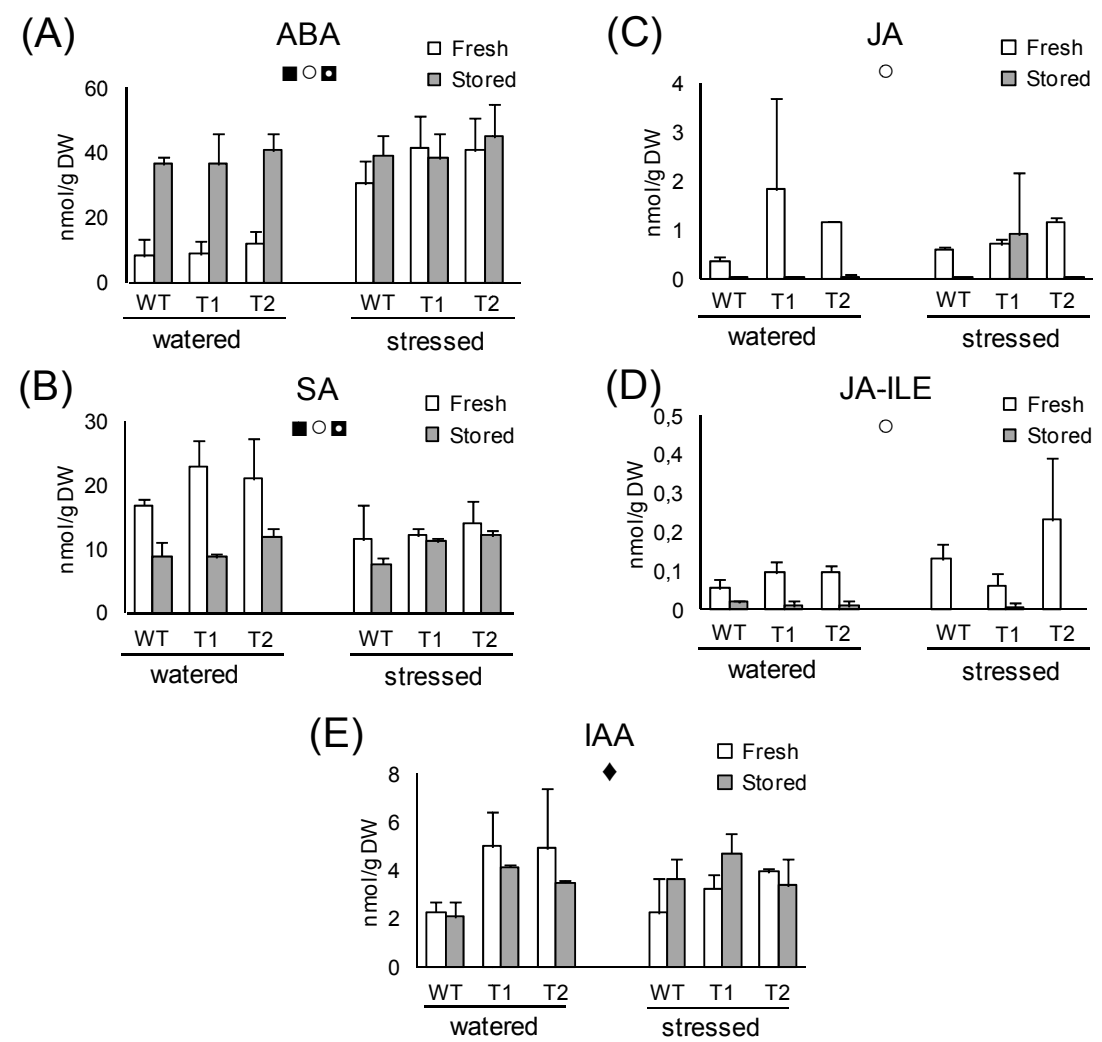

Figure 3. Hormones detected by UHPLC-MS/MS. Bars and error bars represent the mean $\pm \mathrm{SD}$ of the same groups of tubers described in the legend of Figure 2. Significant differences (one-way MANOVA, $P<0.05$;

Supplementary Table 2) between the tubers of well-watered and drought-stressed plants are indicated by $\mathbf{m}$, and those between fresh and stored tubers are indicated by $\circ$. Interactions between stress and storage are indicated by $\mathbf{D}$.

WT, wild-type; T1 and T2, TPS1 lines; DW, dry weight

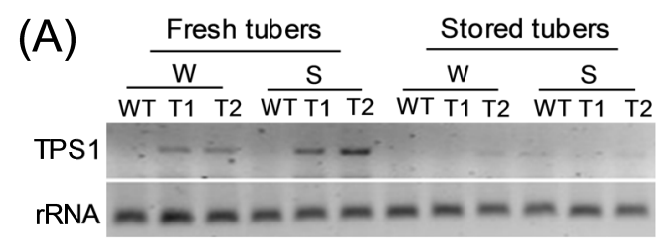

(B)

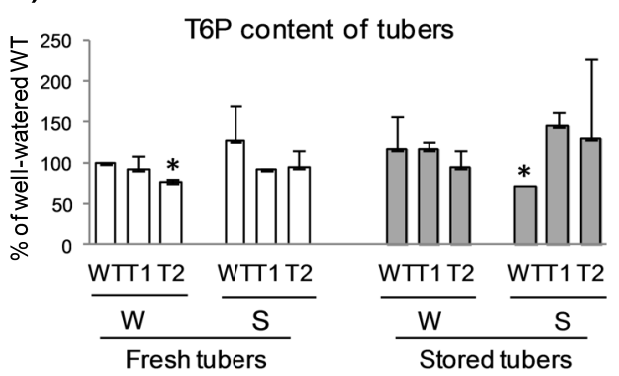

Figure 4. TPS1 expression and T6P levels in tubers. (A) RT-PCR analysis of TPS1 transgene expression in tubers of well-watered and drought-stressed plants. RT-PCR analysis of 18S RNA was used as a control. (B) Relative T6P levels of the tubers. RNA and T6P were isolated from the same groups of tubers described in the legend of Figure 2. The average T6P concentrations in freshly harvested tubers of well-watered WT plants in the two independent experiments were 255 and $123 \mathrm{nmol} \mathrm{g}^{-1} \mathrm{DW}$. These values are considered $100 \%$ for comparisons with the other samples in the same experiments. The error bars denote the SD; ${ }^{*} P<0.01$ (Student's $t$ test); WT, wild-type; T1 and

T2, TPS1 lines; DW, dry weight 


\section{Discussion}

\subsection{Effect of Stress on Tuber Yield and Metabolite Composition}

In this study, the tuber yield and quality of the commercial cv. White Lady and TPS1 transgenic lines in this background, T1 and T2, were compared. Drought stress reduces photosynthesis, plant biomass, and tuber yield almost proportionally to the rate of water consumption (Monneveux et al., 2013). In our study, periodic drought resulted in an average yield loss of 50\% in WT and 20-40\% in TPS1 transgenic plants. Nonetheless, the average tuber mass of WT plants remained higher than that of the T1 and T2 plants. This result might be due to the lower $\mathrm{CO}_{2}$ fixation rate and lower fresh mass of the TPS1 transgenic plants compared to WT (Stiller et al., 2008).

Periodic drought reduced the size but increased the number of tubers, especially for WT plants. The large number of small tubers indicates that tuber formation was not inhibited. This phenotype is similar to that of sugar-storing starch-deficient mutants, which are unable to convert sucrose to starch in the tuber and have low sink strength (Müller-Röber et al., 1992). However, we did not observe a significant increase in sucrose concentration (Figure 2E), suggesting that factors other than sugar-storing ability also influence sink strength.

Drought stress increased the proline content of tubers from a barely detectable level to $130 \mu \mathrm{mol} \mathrm{g}^{-1} \mathrm{DW}$ (Figure 2F). An increase in proline content triggered by stress in the leaves of various plant species is a well-documented response (Obata \& Fernie, 2012), and proline accumulation was found to be induced by high salinity, drought, and selenium in tubers (Teixeira \& Pereira, 2007; Maggio et al., 2008; Jezek et al., 2011). Glutamine synthetase plays a key role in nitrogen metabolism and has been implicated in the regulation of proline levels in plants (Brugiere et al., 1999). This enzyme is activated in growing tubers in response to drought (Teixeira \& Pereira, 2007). In a field experiment, glutamine and glutamate showed the greatest changes in response to various treatments (Maggio et al., 2008). We also observed 2-fold increases in glutamine and glutamate in stressed tubers (Supplementary Figure 1). Asparagine accumulation appears to be another general response of tubers to water limitation because it was detected in the cvs. Agria and Merit (Maggio et al., 2008) as well as in cv. White Lady (Figure 2G). Phenylalanine showed an approximate 5-fold increase in freshly harvested tubers of stressed plants compared to well-watered plants (Figure $2 \mathrm{H}$ ) that can be transformed into lignins, phenolic acids, flavonoids, stilbenes, and lignans (Boudet, 2007).

The amino acids proline, asparagine, and phenylalanine, which showed the greatest increases during drought stress, are synthesised via various pathways. These pathways, however, are interconnected via carbon metabolism (Figure 5). The Arabidopsis ASN1 gene encodes asparagine synthase, which synthesises asparagine and glutamate from aspartate and glutamine, respectively, and is one of the genes that is most affected by sugar. Proline metabolism is similarly regulated through the transcriptional regulation of the P5CS gene, which encodes $\Delta$ 1-pyrroline-5-carboxylate synthetase. In Arabidopsis, both genes are regulated by the transcription factor bZIP11, which is repressed by sucrose. Interestingly, it was also shown that increased bZIP11 expression leads to increased phenylalanine levels (Hanson et al., 2008). Although the regulatory circuits are not well known in potatoes, it appears likely that glutamine is mobilised to tubers, where it is converted into asparagine by the asparagine synthase StAst1 (Chawla et al., 2012). Interestingly however, we could not detect any change in the sucrose level upon drought stress in either leaves (Kondrák et al., 2012) or tubers of WT plants (Figure 2E). Thus, we concluded that the activity of the transcription factor(s) controlling proline, asparagine, and phenylalanine synthesis in potato may not depend on sucrose.

In addition to proline, raffinose levels were greatly increased (11-fold) upon drought stress in leaves (Kondrák et al., 2012) but not in tubers of the same plants (Supplementary Figure 1), indicating that source and sink organs respond to the same stress through mechanisms that are at least partially different.

Drought stress increased the ABA concentration while decreasing the SA concentration of tubers (Figure 3A \& $3 \mathrm{~B})$. Thus, the condition-specific positive/negative interaction between ABA and SA that exists in other plant organs (Acharya \& Assmann, 2009) may also exist in tubers. 


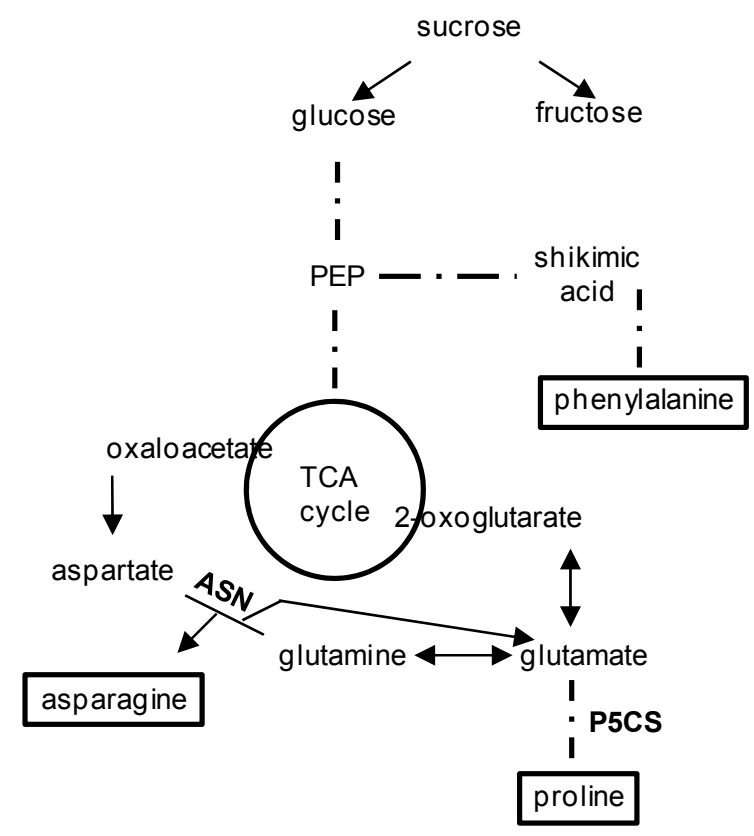

Figure 5. Metabolic pathways leading to the biosynthesis of asparagine, proline, and phenylalanine. Dashed lines symbolise multistep reactions, and solid lines symbolise one-step reactions. ASN, asparagine synthase; P5CS,

$\Delta$ 1-pyrroline-5-carboxylate synthetase

\subsection{Effect of Storage on the Metabolite and Hormone Compositions of Tubers}

The length of the dormancy period depends on both the genetic background and the environmental conditions during tuber development and storage. GAs and CKs are generally considered to be growth promoters, whereas ABA and ET are believed to inhibit sprout growth (S. Sonnewald \& U. Sonnewald, 2013). Although the level of GAs in tuber tissues is below the detection limit (Lytovchenko et al., 2005; Morris et al., 2006), we attempted to estimate the level of CKs in WT and TPS1 transgenic tubers using a bioassay based on chlorophyll formation in cucumber cotyledons (Fletcher \& McCullagh, 1971). Unfortunately, the level of CKs was under the detection level of $0.1 \mu \mathrm{g} \mathrm{ml}^{-1}$ 6-benzylaminopurine (data not shown). In contrast, ABA was present at detectable levels in all tuber samples. Surprisingly however, we observed a 4-fold increase in the ABA concentration of stored tubers harvested from well-watered plants (Figure 3A). Previously, a continuous decline in the ABA content of tubers of various potato varieties was detected during storage. However, this decline did not correlate with the sprouting behaviour of the tubers (Suttle, 1995; Biemelt et al., 2000). Thus, our finding may reflect a cultivar-specific difference or indicate a specific period, namely the early phase of sprout development, when the ABA level may be increased due to tuber water loss.

Similar to stress, storage increased the tuber asparagine concentration (Figure 2G). A massive increase in the asparagine level was previously noted in the Pentland Dell and Bintje varieties when they were stored for a long period of time (Brierley et al., 1997; De Wilde et al., 2005). The asparagine content of Bintje reached $17 \mathrm{mg} \mathrm{g}^{-1}$ DW (De Wilde et al., 2005), which is comparable to the $101 \mu \mathrm{mol} \mathrm{g}^{-1} \mathrm{DW}$ (Figure 2G) (equivalent to $13.2 \mathrm{mg} \mathrm{g}^{-1}$ DW) observed in stored tubers of well-watered White Lady plants.

One of the most interesting findings of this study was that the levels of two metabolites, mannose and phenylalanine, and two hormones, ABA and SA, were different in tubers of stressed and non-stressed plants upon storage. While the concentrations of mannose, phenylalanine, and ABA in tubers of well-watered plants increased upon storage, they remained the same or even decreased in the stored tubers of stressed plants (Figures 2D \& 2H; Figure 3A). However, while the SA concentration in tubers of well-watered plants decreased upon storage, it did not change significantly in the stored tubers of stressed plants (Figure 3B). The physiological importance of these differences remains obscure.

\subsection{Effect of TPS1 Expression on the Dormancy and Metabolite Composition of Tubers}

The expression of yeast TPS1 resulted in a longer dormancy period and altered the concentrations of 13 metabolites compared to their levels in WT tubers. However, the general changes in metabolite concentrations in 
stored WT and TPS1 tubers were very similar and depended mainly on the environmental conditions in which the plants were grown rather than on the genotype of the plants. This result indicates that the differences detected between the freshly harvested and stored tubers are more likely to reflect the tuber aging process rather than the developmental stage of sprouting.

The expression of the E. coli TPS-encoding gene OtsA driven by the strong tuber-specific patatin promoter $B 33$ significantly delayed tuber sprouting compared with WT. The delay in the sprouting of the B33-OtsA lines correlated with the T6P content of the tubers, which reached $46 \mathrm{nmol} \mathrm{g}^{-1}$ fresh weight (FW) in the transgenic line with the highest level of $\mathrm{O} t s A$ expression. Thus, it was concluded that the T6P levels either directly or indirectly affect tuber dormancy (Debast et al., 2011). In the T1 and T2 transgenic lines, the yeast TPS1 gene was expressed from the drought-inducible StDS2 promoter. However, due to "leaky" transcriptional regulation, the TPS1 gene was also expressed in the tubers of well-watered plants (Figure 4A). Although this expression did not result in a significant increase in the T6P level, which was between 123 and $255 \mathrm{nmol} \mathrm{g}^{-1} \mathrm{DW}$ (approximately 20-50 nmol g${ }^{-1} \mathrm{FW}$ ) in WT tubers (Figure 4B), the dormancy period of the transgenic tubers was prolonged. Thus, although our result supports the previous finding that TPS has a role in the maintenance of dormancy, it indicates that T6P is unlikely to have an effect on the duration of dormancy.

\section{Conclusion}

Expression of yeast TPS1, even at a low level, has a pleiotropic effect on potato plants at phenotypic, transcriptional, and metabolic levels in both leaves and tubers. Weak expression of TPS1 does not increase the concentration of T6P or trehalose in either leaves or tubers. Thus, it is not the amounts of these metabolites per se that are responsible for the pleiotropic effects, including delayed leaf wilting and prolonged dormancy of tubers compared to WT. Previously, it has been shown that cauliflower TPS and Arabidopsis TPS5, TPS6, and TPS7 can bind to 14-3-3 proteins if the $\mathrm{Ser}^{22}$ and $\mathrm{Thr}^{49}$ residues are phosphorylated (Moorhead et al., 1999; Harthill et al., 2006). Because the TPS1 protein of yeast is 40\% identical to TPS5 and TPS1 contains Ser and Thr residues in the same locations as the Ser and Thr residues in Arabidopsis TPS isoforms, we postulate that phosphorylation of yeast TPS1 and its interaction with 14-3-3 proteins may also occur in potato. Binding of yeast TPS1 to 14-3-3 proteins can influence the activities of housekeeping proteins such as nitrate reductase and may lead to an imbalance in ion homeostasis and hormone signalling, processes in which 14-3-3 proteins have well-understood functions (Oecking \& Jaspert, 2009). Taken together, these processes may result in the alterations that were detected in TPS1 transgenic potatoes.

\section{References}

Acharya, B. R., \& Assmann, S. M. (2009). Hormone interactions in stomatal function. Plant Molecular Biology, 69, 451-462. http://dx.doi.10.1007/s11103-008-9427-0

Bachem, C., Van der Hoeven, R., Lucker, J., Oomen, R., Casarini, E., Jacobsen, E., \& Visser, R. (2000). Functional genomic analysis of potato tuber life-cycle. Potato Research, 43, 297-312.

Biemelt, S., Hajirezaei, M., Hentschel, E., \& Sonnewald, U. (2000). Comparative analysis of abscisic acid content and starch degradation during storage of tubers harvested from different potato varieties. Potato Research, $43,371-382$.

Boudet, A. (2007). Evolution and current status of research in phenolic compounds. Phytochemistry, 68, 2722-2735. http://dx.doi.org/10.1016/j.phytochem.2007.06.012

Brierley, E. R., Bonner, P. L. R., \& Cobb, A. H. (1997). Aspects of amino acid metabolism in stored potato tubers (cv. Pentland Dell). Plant Science, 127, 17-24. http://dx.doi.org/10.1016/S0168-9452(97)00109-X

Brugiere, N., Dubois, F., Limami, A. M., Lelandais, M., Roux, Y., Sangwan, R. S., \& Hirel, B. (1999). Glutamine synthetase in the phloem plays a major role in controlling proline production. The Plant Cell, 11, 1995-2012. http://dx.doi.org/10.1105/tpc.11.10.1995

Cattivelli, L., Rizza, F., Badeck, E.-W., Mazzucotelli, E., Mastrangelo, A. M., Francia, E., ... Stanca, A. M. (2008). Drought tolerance improvement in crop plants: An integrated view from breeding to genomics. Field Crops Research, 105, 1-14. http://dx.doi.org/10.1016/j.fcr.2007.07.004

Chawla, R., Shakya, R., \& Rommens, C. M. (2012). Tuber-specific silencing of asparagine synthetase-1 reduces the acrylamide-forming potential of potatoes grown in the field without affecting tuber shape and yield. Plant Biotechnology Journal, 10, 913-924. http://dx.doi.10.1111/j.1467-7652.2012.00720.x

Debast, S., Nunes-Nesi, A., Hajirezaei, M. R., Hofmann, J., Sonnewald, U., Fernie, A. R., \& Börnke, F. (2011). Altering trehalose-6-phosphate content in transgenic potato tubers affects tuber growth and alters 
responsiveness to hormones during sprouting. Plant Physiology, 156, 1754-1771. http://dx.doi.10.1104/pp.111.179903

De Wilde, T., De Meulenaer, B., Mestdagh, F., Govaert, Y., Vandeburie, S., Ooghe, W., ... Verhe, R. A. (2005). Influence of storage practices on acrylamide formation during potato frying. Journal of Agricultural \& Food Chemistry, 53, 6550-6557. http://dx.doi. 10.1021/jf050650s

Dóczi, R., Csanaki, C., \& Bánfalvi, Z. (2002). Expression and promoter activity of the desiccation-specific Solanum tuberosum gene StDS2. Plant Cell \& Environment, 25, 1197-1203. http://dx.doi.10.1046/j.1365-3040.2002.00904.x

Elbein, A. D., Pan, Y. T., Pastuszak, I., \& Carroll, D. (2003). New insights on trehalose: A multifunctional molecule. Glycobiology, 13, 17R-27R. http://dx.doi.10.1093/glycob/cwg047

Fletcher, R. A., \& McCullagh, D. (1971). Cytokinin-induced chlorophyll formation in cucumber cotyledons. Planta, 101, 88-90.

Garg, A., Kim, J., Owens, T., Ranwala, A., Choi, Y., Kochian, L., \& Wu, R. (2002). Trehalose accumulation in rice plants confers high tolerance levels to different abiotic stresses. Proceedings of National Academy of Sciences U. S. A., 99, 15898-15903. http://dx.doi.10.1073/pnas.252637799

Glauser, G., Vallat, A., \& Balmer, D. (2014). Hormone profiling. In J. Salinas \& J. J. Sanchez-Serrano (Eds.) Arabidopsis Protocols Series: Methods in Molecular Biology (pp. 597-608, 3rd ed.). Humana Press. http://dx.doi.10.1007/978-1-62703-580-4_31

Gregory, P. J., \& Simmonds, L. P. (1992). Water relations and growth of potatoes. In P. M. Harris (Ed.) The potato crop - The scientific basis for improvement (pp. 214-216, 2 ed.). Chapman and Hall, London. http://dx.doi.10.1007/978-94-011-2340-2_5

Hanson, J., Hanssen, M., Wiese, A., Hendriks, M. M. W. B., \& Smeekens, S. (2008). The sucrose regulated transcription factor bZIP11 affects amino acid metabolism by regulating the expression of ASPARAGINE SYNTHETASE1 and PROLINE DEHYDROGENASE2. The Plant Journal, 53, 935-949. http://dx.doi.10.1111/j.1365-313X.2007.03385.x

Harthill, J. E., Meek, S. E., Morrice, N., Peggie, M. W., Borch, J., Wong, B. H. C., \& Mackintosh, C. (2006). Phosphorylation and 14-3-3 binding of Arabidopsis trehalose-phosphate synthase 5 in response to 2-deoxyglucose. The Plant Journal, 47, 211-223. http://dx.doi.10.1111/j.1365-313X.2006.02780.x

Jezek, P., Hlusek, J., Losak, T., Juzl, M., Elzner, P., Kracmar, S., .. Martensson, A. (2011). Effect of foliar application of selenium on the content of selected amino acids in potato tubers (Solanum tuberosum L.). Plant Soil \& Environment, 57, 315-320.

Kim, S., Yun, E. J., Hossain, M. A., Lee, H., \& Kim, K. H. (2012). Global profiling of ultraviolet-induced metabolic disruption in Melissa officinalis by using gas chromatography-mass spectrometry. Analitical \& Bioanalitical Chemistry, 404, 553-562. http://dx.doi.10.1007/s00216-012-6142-0

Kondrák, M., Marincs, F., Antal, F., Juhász, Z., \& Bánfalvi, Z. (2012). Effects of yeast trehalose-6-phosphate synthase 1 on gene expression and carbohydrate contents of potato leaves under drought stress conditions. BMC Plant Biology, 12, 74. http://dx.doi.10.1186/1471-2229-12-74

Kondrák, M., Marincs, F., Kalapos, B., Juhász, Z., \& Bánfalvi, Z. (2011). Transcriptome analysis of potato leaves expressing the trehalose-6-phosphate synthase 1 gene of yeast. PLoS ONE, 6, e23466. http://dx.doi.10.1371/journal.pone.0023466

Lunn, J. E., Feil, R., Hendriks, J. H., Gibon, Y., Morcuende, R., Osuna, D., ... Stitt, M. (2006). Sugar-induced increases in trehalose 6-phosphate are correlated with redox activation of ADPglucose pyrophosphorylase and higher rates of starch synthesis in Arabidopsis thaliana. Biochemical Journal, 397, 139-148. http://dx.doi.10.1042/BJ20060083

Lytovchenko, A., Hajirezaei, M., Eickmeier, I., Mittendorf, V., Sonnewald, U., Willmitzer, L., \& Fernie, A. R. (2005). Expression of an Escherichia coli phosphoglucomutase in potato (Solanum tuberosum L.) results in minor changes in tuber metabolism and a considerable delay in tuber sprouting. Planta, 221, 915-927. http://dx.doi.10.1007/s00425-005-1490-z

Maggio, A., Carillo, P., Bulmetti, G. S., Fuggi, A., Barbieri, G., \& De Pascale, S. (2008). Potato yield and metabolic profiling under conventional and organic farming. European Journal of Agronomy, 28, 343-350. http://dx.doi.org/10.1016/j.eja.2007.10.003 
Monneveux, P., Ramírez, D. A., \& Pino, M.-T. (2013). Drought tolerance in potato (S. tuberosum L): Can we learn from drought tolerance research in cereals? Plant Science, 205-206, 76-86. http://dx.doi.org/10.1016/j.plantsci.2013.01.011

Moorhead, G., Douglas, P., Cotelle, V., Harthill, J., Morrice, N., Meek, S., ... MacKintosh C (1999) Phosphorylation-dependent interactions between enzymes of plant metabolism and 14-3-3 proteins. The Plant Journal, 18, 1-12.

Morris, W. L., Ducreux, L. J. M., Hedden, P., Millam, S., \& Taylor, M. A. (2006). Overexpression of a bacterial 1-deoxy-D-xylulose 5-phosphate synthase gene in potato tubers perturbs the isoprenoid metabolic network: implications for the control of the tuber life cycle. Journal of Experimental Botany, 57, 3007-3018. http://dx.doi.10.1093/jxb/er1061

Murashige, T., \& Skoog, F. (1962). A revised medium for rapid growth and bioassays with tobacco tissue culture. Physiologia Plantarum, 15, 473-497. http://dx.doi.10.1111/j.1399-3054.1962.tb08052.x

Müller-Röber, B., Sonnewald, U., \& Stitt, M. (1992). Antisense inhibition of the ADP-glucose pyrophosphorylase in transgenic potato leads to sugar-storing tubers and influences tuber formation and expression of tuber storage protein genes. EMBO Journal, 11, 1229-1238.

Obata, T., \& Fernie, A. R. (2012). The use of metabolomics to dissect plant responses to abiotic stresses. Cellular \& Molecular Life Sciences, 69, 3225-3243. http://dx.doi.10.1007/s00018-012-1091-5

Oecking, C., \& Jaspert, N. (2009). Plant 14-3-3 proteins catch up with their mammalian orthologs. Current Opinion in Plant Biology, 12, 760-765. http://dx.doi.org/10.1016/j.pbi.2009.08.003

Schauer, N., Zamir, D., \& Fernie, A. R. (2005). Metabolic profiling of leaves and fruit of wild species tomato: a survey of the Solanum lycopersicum complex. Journal of Experimental Botany, 56, 297-307. http://dx.doi.10.1093/jxb/eri057

Sonnewald, S., \& Sonnewald, U. (2013). Regulation of potato tuber sprouting. Planta, 239, 27-38. http://dx.doi.10.1007/s00425-013-1968-z

Stiekema, W. J., Heidekamp, F., Dirkse, W. G., van Beckum, J., de Haan, P., ten Bosh, C., \& Louwerse, J. D. (1988). Molecular cloning and analysis of four potato tuber mRNAs. Plant Molecular Biology, 11, $255-269$. http://dx.doi.10.1007/BF00027383

Stiller, I., Dulai, S., Kondrák, M., Tarnai, R., Szabó, L., Toldi, O., \& Bánfalvi, Z. (2008). Effects of drought on water content and photosynthetic parameters in potato plants expressing the trehalose-6-phosphate synthase gene of Saccharomyces cerevisiae. Planta, 227, 299-308. http://dx.doi.10.1007/s00425-007-0617-9

Suttle, J. C. (1995). Postharvest changes in endogenous ABA levels and ABA metabolism in relation to dormancy in potato tubers. Physiologia Plantarum, 95, 233-240. http://dx.doi.10.1111/j.1399-3054.1995.tb00832.x

Teixeira, J., \& Pereira, S. (2007). High salinity and drought act on an organ-dependent manner on potato glutamine synthetase expression and accumulation. Environmental \& Experimental Botany, 60, 121-126. http://dx.doi.org/10.1016/j.envexpbot.2006.09.003

Thiele, A., Herold, M., Lenk, I., Quail, P. H., \& Gatz, C. (1999). Heterologous expression of Arabidopsis phytochrome B in transgenic potato influences photosynthetic performance and tuber development. Plant Physiology, 120, 73-82. http://dx.doi.org/10.1104/pp.120.1 


\section{Appendixs}
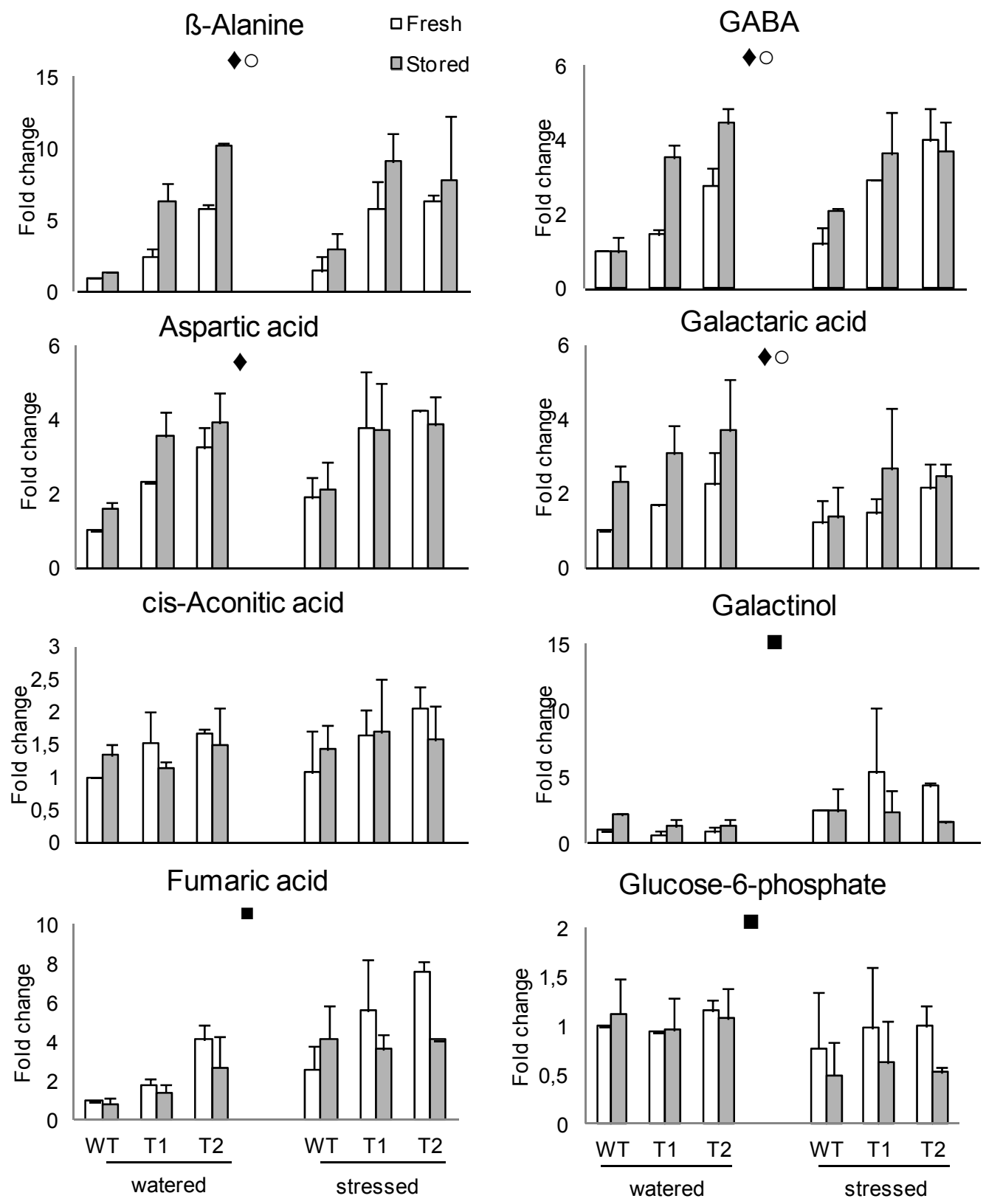


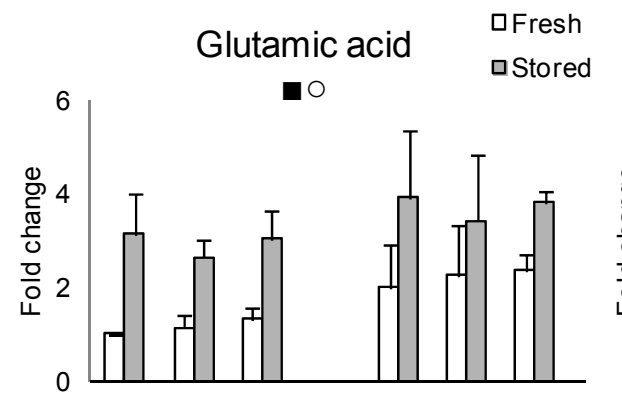

Glutamine

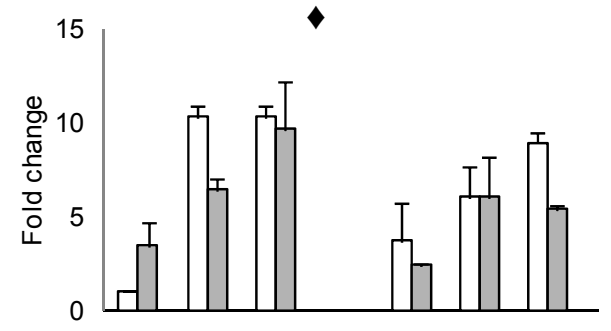

Glyceric acid

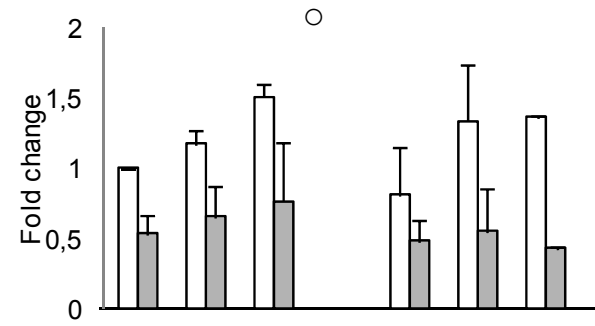

Glycine

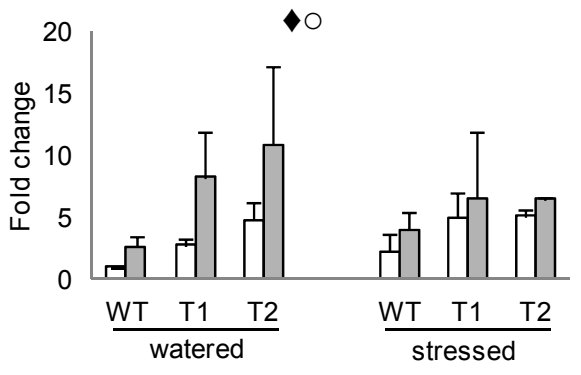

Inositol
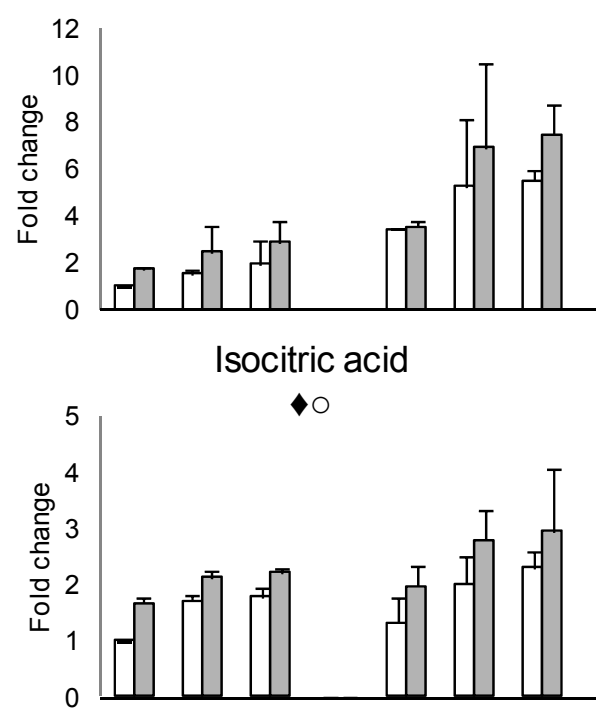

Isoleucine
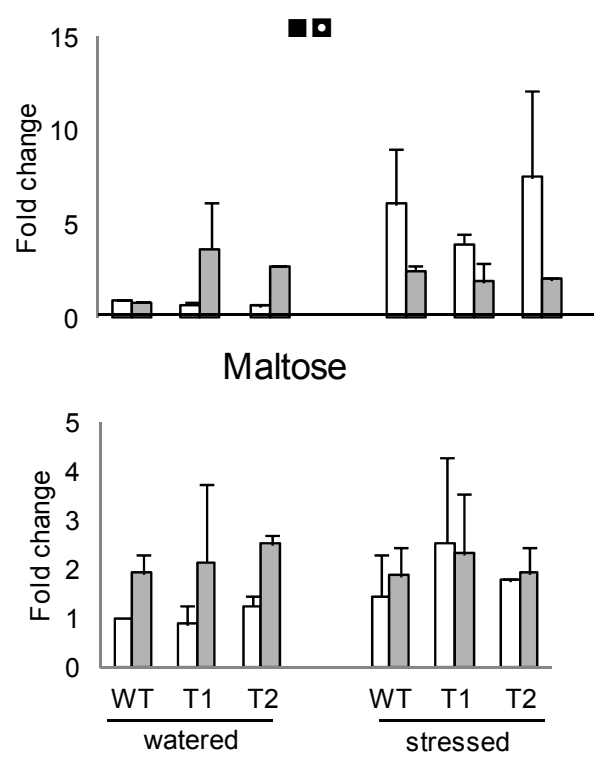

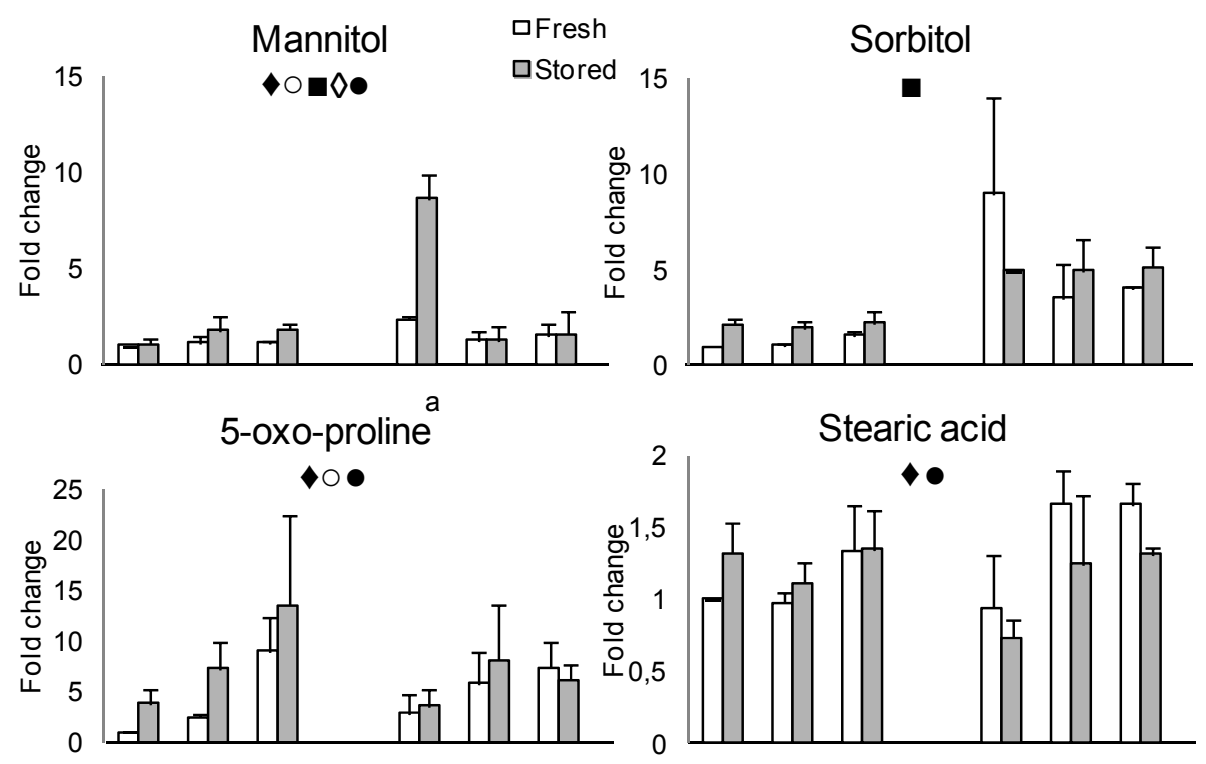

Palmitic acid

\section{Threonine}
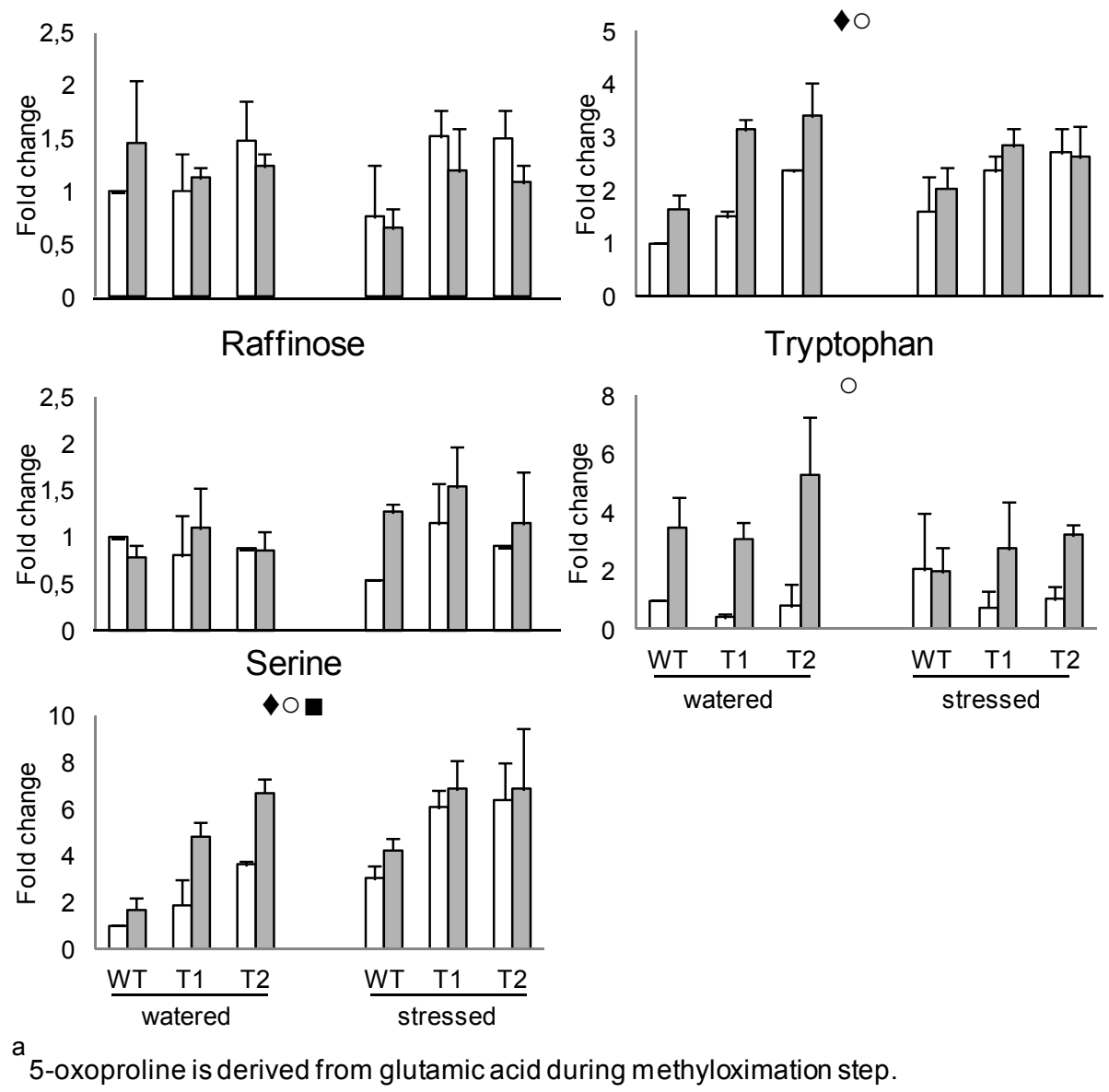

Supplementary Figure 1. Metabolites detected by GC-MS. The bars and error bars represent the mean $\pm \mathrm{SD}$ of the same groups of tubers described in the legend of Figure 2. Significant differences (one way MANOVA, $P<$ 0.05 ) between tubers of well-watered and drought-stressed plants are indicated by $\mathbf{m}$, those between fresh and stored tubers are indicated by $\circ$, and those between WT and TPS1 tubers are indicated by $\$$. Interactions between stress and storage $\mathbf{a}$, genotype and storage $\diamond$, and genotype and stress are indicated by $\bullet$. WT, wild-type; T1, T2, TPS1 lines; DW, dry weight 
Table S1. Significant differnces $(\mathrm{P}<0.05)$ are highlighted by colours

\begin{tabular}{|c|c|c|c|c|c|c|c|c|c|}
\hline \multicolumn{10}{|c|}{ Tests of Between-Subjects Effects } \\
\hline Source & $\begin{array}{l}\text { Dependent } \\
\text { Variable }\end{array}$ & $\begin{array}{l}\text { Type III } \\
\text { Sum of } \\
\text { Squares }\end{array}$ & $\mathrm{df}$ & $\begin{array}{l}\text { Mean } \\
\text { Square }\end{array}$ & $\mathrm{F}$ & Sig. & $\begin{array}{l}\text { Partial Eta } \\
\text { Squared }\end{array}$ & $\begin{array}{l}\text { Noncent. } \\
\text { Parameter }\end{array}$ & $\begin{array}{l}\text { Observed } \\
\text { Power }^{\mathrm{b}}\end{array}$ \\
\hline \multicolumn{10}{|l|}{ Genotype } \\
\hline & $\begin{array}{l}\text { Fructose }(217, \\
307)\end{array}$ & $1.899 \mathrm{E} 14$ & 2 & $9.494 \mathrm{E} 13$ & 1.780 & .210 & .229 & 3.559 & .300 \\
\hline & Mannose & $3.128 \mathrm{E} 12$ & 2 & $1.564 \mathrm{E} 12$ & .146 & .866 & .024 & .291 & .068 \\
\hline & Galactose & $3.728 \mathrm{E} 15$ & 2 & $1.864 \mathrm{E} 15$ & .072 & .931 & .012 & .144 & .059 \\
\hline & Glucose & $1.319 \mathrm{E} 15$ & 2 & $6.594 \mathrm{E} 14$ & .833 & .458 & .122 & 1.666 & .160 \\
\hline & Sorbitol & $3.592 \mathrm{E} 14$ & 2 & $1.796 \mathrm{E} 14$ & 2.696 & .108 & .310 & 5.391 & .433 \\
\hline & Inositol & $4.072 \mathrm{E} 17$ & 2 & $2.036 \mathrm{E} 17$ & 1.975 & .181 & .248 & 3.949 & .329 \\
\hline & Sucrose & $4.043 \mathrm{E} 17$ & 2 & $2.021 \mathrm{E} 17$ & .588 & .571 & .089 & 1.176 & .126 \\
\hline & Maltose & $1.441 \mathrm{E} 12$ & 2 & $7.207 \mathrm{E} 11$ & .596 & .567 & .090 & 1.191 & .127 \\
\hline & L-Isoleucine (158) & $2.269 \mathrm{E} 13$ & 2 & $1.134 \mathrm{E} 13$ & .334 & .723 & .053 & .667 & .092 \\
\hline & L-Proline (142) & $3.161 \mathrm{E} 16$ & 2 & $1.581 \mathrm{E} 16$ & 1.109 & .362 & .156 & 2.218 & .200 \\
\hline & Glycine (174) & $1.284 \mathrm{E} 14$ & 2 & $6.422 \mathrm{E} 13$ & 17.724 & .000 & .747 & 35.448 & .998 \\
\hline & $\begin{array}{l}\text { Glyceric acid } \\
(189,292)\end{array}$ & $3.048 \mathrm{E} 10$ & 2 & $1.524 \mathrm{E} 10$ & 7.022 & .010 & .539 & 14.044 & .846 \\
\hline & $\begin{array}{l}\text { Fumaric acid } \\
(245)\end{array}$ & $2.426 \mathrm{E} 12$ & 2 & $1.213 \mathrm{E} 12$ & 5.807 & .017 & .492 & 11.614 & .769 \\
\hline & $\begin{array}{l}\text { L-Serine (204, } \\
\text { 218) }\end{array}$ & $3.428 \mathrm{E} 14$ & 2 & $1.714 \mathrm{E} 14$ & 21.727 & .000 & .784 & 43.453 & 1.000 \\
\hline & $\begin{array}{l}\text { L-Threonine (218, } \\
\text { 291) }\end{array}$ & $4.016 \mathrm{E} 12$ & 2 & $2.008 \mathrm{E} 12$ & 15.182 & .001 & .717 & 30.364 & .994 \\
\hline & beta-Alanine (248) & $1.007 \mathrm{E} 13$ & 2 & $5.036 \mathrm{E} 12$ & 24.873 & .000 & .806 & 49.747 & 1.000 \\
\hline & $\begin{array}{l}\text { Aspartic acid } \\
(232)\end{array}$ & $4.871 \mathrm{E} 15$ & 2 & $2.436 \mathrm{E} 15$ & 27.981 & .000 & .823 & 55.961 & 1.000 \\
\hline & 5-oxo-Proline & $3.096 \mathrm{E} 15$ & 2 & $1.548 \mathrm{E} 15$ & 48.531 & .000 & .890 & 97.062 & 1.000 \\
\hline & GABA $(304,174)$ & $9.287 \mathrm{E} 16$ & 2 & $4.643 \mathrm{E} 16$ & 38.114 & .000 & .864 & 76.228 & 1.000 \\
\hline & $\begin{array}{l}\text { Glutamic acid } \\
(246)\end{array}$ & $6.948 \mathrm{E} 15$ & 2 & $3.474 \mathrm{E} 15$ & 1.046 & .381 & .148 & 2.092 & .191 \\
\hline & $\begin{array}{l}\text { L-Phenylalanine } \\
(218,192)\end{array}$ & $7.370 \mathrm{E} 14$ & 2 & $3.685 \mathrm{E} 14$ & 5.333 & .022 & .471 & 10.667 & .731 \\
\hline & $\begin{array}{l}\text { L-Asparagine } \\
(188,231)\end{array}$ & $4.343 \mathrm{E} 17$ & 2 & 2.172E17 & 20.388 & .000 & .773 & 40.776 & .999 \\
\hline & $\begin{array}{l}\text { cis-Aconitic acid } \\
(229,375)\end{array}$ & $1.622 \mathrm{E} 12$ & 2 & $8.112 \mathrm{E} 11$ & 3.100 & .082 & .341 & 6.200 & .488 \\
\hline & Glutamine (156) & $2.765 \mathrm{E} 16$ & 2 & $1.383 \mathrm{E} 16$ & 38.095 & .000 & .864 & 76.190 & 1.000 \\
\hline & $\begin{array}{l}\text { Isocitric acid } \\
(273)\end{array}$ & $1.948 \mathrm{E} 18$ & 2 & $9.740 \mathrm{E} 17$ & 8.206 & .006 & .578 & 16.413 & .899 \\
\hline & D-Mannitol (319) & $1.818 \mathrm{E} 15$ & 2 & $9.088 \mathrm{E} 14$ & 19.752 & .000 & .767 & 39.505 & .999 \\
\hline & $\begin{array}{l}\text { Palmitic acid (313, } \\
314)\end{array}$ & $8.188 \mathrm{E} 12$ & 2 & $4.094 \mathrm{E} 12$ & 3.458 & .065 & .366 & 6.915 & .534 \\
\hline & $\begin{array}{l}\text { Galactaric acid } \\
(333)\end{array}$ & $7.076 \mathrm{E} 12$ & 2 & $3.538 \mathrm{E} 12$ & 9.934 & .003 & .623 & 19.869 & .947 \\
\hline
\end{tabular}




\begin{tabular}{|c|c|c|c|c|c|c|c|c|c|}
\hline & L-Tryptophan 202 & $2.012 \mathrm{E} 13$ & 2 & $1.006 \mathrm{E} 13$ & 2.691 & .108 & .310 & 5.382 & .432 \\
\hline & $\begin{array}{l}\text { Stearic acid } \\
(341,117)\end{array}$ & $1.931 \mathrm{E} 13$ & 2 & $9.657 \mathrm{E} 12$ & 10.810 & .002 & .643 & 21.619 & .962 \\
\hline & $\begin{array}{l}\text { Glucose-6-phosph } \\
\text { ate }(387)\end{array}$ & $2.356 \mathrm{E} 12$ & 2 & $1.178 \mathrm{E} 12$ & .536 & .599 & .082 & 1.072 & .119 \\
\hline & Raffinose (437) & $1.625 \mathrm{E} 12$ & 2 & $8.125 \mathrm{E} 11$ & 1.062 & .376 & .150 & 2.124 & .193 \\
\hline & Galactinol (204) & $2.935 \mathrm{E} 12$ & 2 & $1.468 \mathrm{E} 12$ & .038 & .963 & .006 & .077 & .055 \\
\hline \multicolumn{10}{|l|}{ Storage } \\
\hline & $\begin{array}{l}\text { Fructose }(217, \\
307)\end{array}$ & $2.499 \mathrm{E} 14$ & 1 & $2.499 \mathrm{E} 14$ & 4.686 & .051 & .281 & 4.686 & .512 \\
\hline & Mannose & $1.070 \mathrm{E} 15$ & 1 & $1.070 \mathrm{E} 15$ & 99.664 & .000 & .893 & 99.664 & 1.000 \\
\hline & Galactose & 4.192E17 & 1 & 4.192E17 & 16.159 & .002 & .574 & 16.159 & .957 \\
\hline & Glucose & $2.842 \mathrm{E} 16$ & 1 & $2.842 \mathrm{E} 16$ & 35.911 & .000 & .750 & 35.911 & 1.000 \\
\hline & Sorbitol & $2.524 \mathrm{E} 13$ & 1 & $2.524 \mathrm{E} 13$ & .379 & .550 & .031 & .379 & .088 \\
\hline & Inositol & $5.245 \mathrm{E} 16$ & 1 & $5.245 \mathrm{E} 16$ & .509 & .489 & .041 & .509 & .101 \\
\hline & Sucrose & $4.355 \mathrm{E} 18$ & 1 & $4.355 \mathrm{E} 18$ & 12.672 & .004 & .514 & 12.672 & .904 \\
\hline & Maltose & $6.187 \mathrm{E} 12$ & 1 & $6.187 \mathrm{E} 12$ & 5.113 & .043 & .299 & 5.113 & .547 \\
\hline & L-Isoleucine (158) & $6.623 \mathrm{E} 13$ & 1 & $6.623 \mathrm{E} 13$ & 1.948 & .188 & .140 & 1.948 & .251 \\
\hline & L-Proline (142) & $1.116 \mathrm{E} 14$ & 1 & $1.116 \mathrm{E} 14$ & .008 & .931 & .001 & .008 & .051 \\
\hline & Glycine (174) & 7.217E13 & 1 & 7.217E13 & 19.918 & .001 & .624 & 19.918 & .983 \\
\hline & $\begin{array}{l}\text { Glyceric acid } \\
(189,292)\end{array}$ & $1.798 \mathrm{E} 11$ & 1 & $1.798 \mathrm{E} 11$ & 82.841 & .000 & .873 & 82.841 & 1.000 \\
\hline & $\begin{array}{l}\text { Fumaric acid } \\
(245)\end{array}$ & $4.960 \mathrm{E} 11$ & 1 & $4.960 \mathrm{E} 11$ & 2.374 & .149 & .165 & 2.374 & .295 \\
\hline & $\begin{array}{l}\text { L-Serine (204, } \\
\text { 218) }\end{array}$ & $9.901 \mathrm{E} 13$ & 1 & $9.901 \mathrm{E} 13$ & 12.552 & .004 & .511 & 12.552 & .901 \\
\hline & L-Threonine (218, & $1.769 \mathrm{E} 12$ & 1 & $1.769 \mathrm{E} 12$ & 13.377 & .003 & .527 & 13.377 & .918 \\
\hline & beta-alanine (248) & $2.624 \mathrm{E} 12$ & 1 & $2.624 \mathrm{E} 12$ & 12.962 & .004 & .519 & 12.962 & .910 \\
\hline & $\begin{array}{l}\text { Aspartic acid } \\
(232)\end{array}$ & 2.057E14 & 1 & $2.057 \mathrm{E} 14$ & 2.363 & .150 & .165 & 2.363 & .293 \\
\hline & 5-oxo-Proline & $5.432 \mathrm{E} 14$ & 1 & $5.432 \mathrm{E} 14$ & 17.032 & & .587 & 17.032 & .966 \\
\hline & GABA $(304,174)$ & $1.710 \mathrm{E} 16$ & 1 & $1.710 \mathrm{E} 16$ & 14.035 & .003 & .539 & 14.035 & .930 \\
\hline & $\begin{array}{l}\text { Glutamic acid } \\
\text { (246) }\end{array}$ & $2.345 \mathrm{E} 17$ & 1 & $2.345 \mathrm{E} 17$ & 70.608 & .000 & .855 & 70.608 & 1.000 \\
\hline & $\begin{array}{l}\text { L-Phenylalanine } \\
(218,192)\end{array}$ & $1.129 \mathrm{E} 15$ & 1 & $1.129 \mathrm{E} 15$ & 16.342 & .002 & .577 & 16.342 & .959 \\
\hline & $\begin{array}{l}\text { L-Asparagine } \\
(188,231)\end{array}$ & $1.860 \mathrm{E} 17$ & 1 & $1.860 \mathrm{E} 17$ & 17.463 & .001 & .593 & 17.463 & .969 \\
\hline & $\begin{array}{l}\text { cis-Aconitic acid } \\
(229,375)\end{array}$ & $3.238 \mathrm{E} 10$ & 1 & $3.238 \mathrm{E} 10$ & .124 & .731 & .010 & .124 & .062 \\
\hline & Glutamine 156 & $1.528 \mathrm{E} 15$ & 1 & $1.528 \mathrm{E} 15$ & 4.211 & .063 & .260 & 4.211 & .471 \\
\hline & $\begin{array}{l}\text { Isocitric acid } \\
(273)\end{array}$ & $1.370 \mathrm{E} 18$ & 1 & $1.370 \mathrm{E} 18$ & 11.543 & .005 & .490 & 11.543 & .876 \\
\hline & D-Mannitol (319) & $1.009 \mathrm{E} 15$ & 1 & $1.009 \mathrm{E} 15$ & 21.925 & .001 & .646 & 21.925 & .990 \\
\hline
\end{tabular}




\begin{tabular}{|c|c|c|c|c|c|c|c|c|c|}
\hline & $\begin{array}{l}\text { Palmitic acid (313, } \\
314)\end{array}$ & $8.157 \mathrm{E} 11$ & 1 & $8.157 \mathrm{E} 11$ & .689 & .423 & .054 & .689 & .119 \\
\hline & $\begin{array}{l}\text { Galactaric acid } \\
\text { (333) }\end{array}$ & $7.096 \mathrm{E} 12$ & 1 & $7.096 \mathrm{E} 12$ & 19.925 & .001 & .624 & 19.925 & .983 \\
\hline & $\begin{array}{l}\text { L-Tryptophan } \\
\text { (202) }\end{array}$ & $2.155 \mathrm{E} 14$ & 1 & $2.155 \mathrm{E} 14$ & 57.620 & .000 & .828 & 57.620 & 1.000 \\
\hline & $\begin{array}{l}\text { Stearic acid (341, } \\
117)\end{array}$ & $1.272 \mathrm{E} 12$ & 1 & $1.272 \mathrm{E} 12$ & 1.424 & .256 & .106 & 1.424 & .196 \\
\hline & $\begin{array}{l}\text { Glucose-6-phosph } \\
\text { ate }(387)\end{array}$ & 7.229E12 & 1 & 7.229E12 & 3.289 & .095 & .215 & 3.289 & .386 \\
\hline & Raffinose (437) & $2.081 \mathrm{E} 12$ & 1 & $2.081 \mathrm{E} 12$ & 2.720 & .125 & .185 & 2.720 & .330 \\
\hline & Galactinol (204) & $5.553 \mathrm{E} 13$ & 1 & $5.553 \mathrm{E} 13$ & 1.449 & .252 & .108 & 1.449 & .198 \\
\hline Stress & & & & & & & & & \\
\hline & $\begin{array}{l}\text { Fructose }(217, \\
307)\end{array}$ & $6.184 \mathrm{E} 13$ & 1 & $6.184 \mathrm{E} 13$ & 1.159 & .303 & .088 & 1.159 & .168 \\
\hline & Mannose & $1.280 \mathrm{E} 15$ & 1 & $1.280 \mathrm{E} 15$ & $\begin{array}{r}119.27 \\
2\end{array}$ & .000 & .909 & 119.272 & 1.000 \\
\hline & Galactose & $8.712 \mathrm{E} 17$ & 1 & $8.712 \mathrm{E} 17$ & 33.586 & .000 & .737 & 33.586 & 1.000 \\
\hline & Glucose & $3.410 \mathrm{E} 16$ & 1 & $3.410 \mathrm{E} 16$ & 43.090 & .000 & .782 & 43.090 & 1.000 \\
\hline & Sorbitol & $3.412 \mathrm{E} 15$ & 1 & $3.412 \mathrm{E} 15$ & 51.203 & .000 & .810 & 51.203 & 1.000 \\
\hline & Inositol & 5.159E17 & 1 & $5.159 \mathrm{E} 17$ & 5.003 & .045 & .294 & 5.003 & .538 \\
\hline & Sucrose & $5.422 \mathrm{E} 17$ & 1 & $5.422 \mathrm{E} 17$ & 1.578 & .233 & .116 & 1.578 & .212 \\
\hline & Maltose & $1.684 \mathrm{E} 12$ & 1 & $1.684 \mathrm{E} 12$ & 1.392 & .261 & .104 & 1.392 & .192 \\
\hline & L-Isoleucine (158) & $3.789 \mathrm{E} 14$ & 1 & $3.789 \mathrm{E} 14$ & 11.143 & .006 & .481 & 11.143 & .865 \\
\hline & L-Proline (142) & $3.821 \mathrm{E} 17$ & 1 & $3.821 \mathrm{E} 17$ & 26.807 & .000 & .691 & 26.807 & .997 \\
\hline & Glycine (174) & $2.376 \mathrm{E} 11$ & 1 & $2.376 \mathrm{E} 11$ & .066 & .802 & .005 & .066 & .056 \\
\hline & $\begin{array}{l}\text { Glyceric acid } \\
(189,292)\end{array}$ & $5.527 \mathrm{E} 9$ & 1 & $5.527 \mathrm{E} 9$ & 2.547 & .136 & .175 & 2.547 & .312 \\
\hline & $\begin{array}{l}\text { Fumaric acid } \\
(245)\end{array}$ & $3.929 \mathrm{E} 12$ & 1 & $3.929 \mathrm{E} 12$ & 18.807 & .001 & .610 & 18.807 & .978 \\
\hline & $\begin{array}{l}\text { L-Serine (204, } \\
\text { 218) }\end{array}$ & $2.178 \mathrm{E} 14$ & 1 & $2.178 \mathrm{E} 14$ & 27.615 & .000 & .697 & 27.615 & .998 \\
\hline & $\begin{array}{l}\text { L-Threonine (218, } \\
\text { 291) }\end{array}$ & $1.282 \mathrm{E} 11$ & 1 & $1.282 \mathrm{E} 11$ & .970 & .344 & .075 & .970 & .148 \\
\hline & beta-alanine (248) & $4.504 \mathrm{E} 11$ & 1 & $4.504 \mathrm{E} 11$ & 2.225 & .162 & .156 & 2.225 & .279 \\
\hline & $\begin{array}{l}\text { Aspartic acid } \\
(232)\end{array}$ & $6.049 \mathrm{E} 14$ & 1 & $6.049 \mathrm{E} 14$ & 6.950 & .022 & .367 & 6.950 & .678 \\
\hline & $\begin{array}{l}\text { 5-oxo-Proline } \\
(156)\end{array}$ & $3.740 \mathrm{E} 13$ & 1 & $3.740 \mathrm{E} 13$ & 1.173 & .300 & .089 & 1.173 & .170 \\
\hline & GABA $(304,174)$ & $7.345 \mathrm{E} 15$ & 1 & $7.345 \mathrm{E} 15$ & 6.029 & .030 & .334 & 6.029 & .617 \\
\hline & $\begin{array}{l}\text { Glutamic acid } \\
\text { (246) }\end{array}$ & $6.610 \mathrm{E} 16$ & 1 & $6.610 \mathrm{E} 16$ & 19.904 & .001 & .624 & 19.904 & .983 \\
\hline & $\begin{array}{l}\text { L-Phenylalanine } \\
(218,192)\end{array}$ & $2.133 \mathrm{E} 15$ & 1 & $2.133 \mathrm{E} 15$ & 30.875 & .000 & .720 & 30.875 & .999 \\
\hline & $\begin{array}{l}\text { L-Asparagine } \\
(188,231)\end{array}$ & $6.058 \mathrm{E} 17$ & 1 & $6.058 \mathrm{E} 17$ & 56.871 & .000 & .826 & 56.871 & 1.000 \\
\hline
\end{tabular}




\begin{tabular}{|c|c|c|c|c|c|c|c|c|c|}
\hline & $\begin{array}{l}\text { cis-Aconitic acid } \\
(229,375)\end{array}$ & 3.009E11 & 1 & 3.009E11 & 1.150 & .305 & .087 & 1.150 & .167 \\
\hline & Glutamine (156) & $2.416 \mathrm{E} 15$ & 1 & $2.416 \mathrm{E} 15$ & 6.656 & .024 & .357 & 6.656 & .659 \\
\hline & $\begin{array}{l}\text { Isocitric acid } \\
(273)\end{array}$ & $8.620 \mathrm{E} 17$ & 1 & $8.620 \mathrm{E} 17$ & 7.263 & .019 & .377 & 7.263 & .697 \\
\hline & D-Mannitol (319) & $1.285 \mathrm{E} 15$ & 1 & $1.285 \mathrm{E} 15$ & 27.924 & .000 & .699 & 27.924 & .998 \\
\hline & $\begin{array}{l}\text { Palmitic acid (313, } \\
314)\end{array}$ & $6.170 \mathrm{E} 11$ & 1 & $6.170 \mathrm{E} 11$ & .521 & .484 & .042 & .521 & .102 \\
\hline & $\begin{array}{l}\text { Galactaric acid } \\
(333)\end{array}$ & $1.739 \mathrm{E} 12$ & 1 & $1.739 \mathrm{E} 12$ & 4.882 & .047 & .289 & 4.882 & .529 \\
\hline & $\begin{array}{l}\text { L-Tryptophan } \\
(202)\end{array}$ & 7.088E12 & 1 & $7.088 \mathrm{E} 12$ & 1.895 & .194 & .136 & 1.895 & .245 \\
\hline & $\begin{array}{l}\text { Stearic acid } \\
(341,117)\end{array}$ & $9.369 \mathrm{E} 11$ & 1 & $9.369 \mathrm{E} 11$ & 1.049 & .326 & .080 & 1.049 & .157 \\
\hline & $\begin{array}{l}\text { Glucose-6-phosph } \\
\text { ate (387) }\end{array}$ & $2.544 \mathrm{E} 13$ & 1 & $2.544 \mathrm{E} 13$ & 11.573 & .005 & .491 & 11.573 & .877 \\
\hline & Raffinose (437) & $1.314 \mathrm{E} 12$ & 1 & $1.314 \mathrm{E} 12$ & 1.718 & .214 & .125 & 1.718 & .227 \\
\hline & Galactinol (204) & $5.568 \mathrm{E} 14$ & 1 & $5.568 \mathrm{E} 14$ & 14.528 & .002 & .548 & 14.528 & .937 \\
\hline \multicolumn{10}{|l|}{ Genotype * } \\
\hline Storage & $\begin{array}{l}\text { Fructose }(217, \\
307)\end{array}$ & $3.106 \mathrm{E} 14$ & 2 & $1.553 \mathrm{E} 14$ & 2.911 & .093 & .327 & 5.822 & .462 \\
\hline & Mannose & $3.659 \mathrm{E} 13$ & 2 & $1.829 \mathrm{E} 13$ & 1.704 & .223 & .221 & 3.408 & .289 \\
\hline & Galactose & $6.927 \mathrm{E} 16$ & 2 & $3.463 \mathrm{E} 16$ & 1.335 & .300 & .182 & 2.670 & .234 \\
\hline & Glucose & $4.665 \mathrm{E} 15$ & 2 & $2.333 \mathrm{E} 15$ & 2.948 & .091 & .329 & 5.896 & .467 \\
\hline & Sorbitol & $2.950 \mathrm{E} 14$ & 2 & $1.475 \mathrm{E} 14$ & 2.214 & .152 & .270 & 4.427 & .364 \\
\hline & Inositol & $2.003 \mathrm{E} 17$ & 2 & $1.002 \mathrm{E} 17$ & .971 & .406 & .139 & 1.943 & .180 \\
\hline & Sucrose & $1.051 \mathrm{E} 18$ & 2 & $5.253 \mathrm{E} 17$ & 1.529 & .256 & .203 & 3.057 & .263 \\
\hline & Maltose & $2.221 \mathrm{E} 11$ & 2 & $1.110 \mathrm{E} 11$ & .092 & .913 & .015 & .184 & .061 \\
\hline & L-Isoleucine (158) & $7.783 \mathrm{E} 13$ & 2 & $3.892 \mathrm{E} 13$ & 1.145 & .351 & .160 & 2.289 & .206 \\
\hline & L-Proline (142) & $1.359 \mathrm{E} 16$ & 2 & $6.797 \mathrm{E} 15$ & .477 & .632 & .074 & .954 & .111 \\
\hline & Glycine (174) & $6.983 \mathrm{E} 12$ & 2 & $3.492 \mathrm{E} 12$ & .964 & .409 & .138 & 1.927 & .179 \\
\hline & $\begin{array}{l}\text { Glyceric acid } \\
(189,292)\end{array}$ & $1.570 \mathrm{E} 10$ & 2 & $7.851 \mathrm{E} 9$ & 3.618 & .059 & .376 & 7.236 & .554 \\
\hline & $\begin{array}{l}\text { Fumaric acid } \\
(245)\end{array}$ & $1.257 \mathrm{E} 12$ & 2 & $6.286 \mathrm{E} 11$ & 3.009 & .087 & .334 & 6.018 & .476 \\
\hline & $\begin{array}{l}\text { L-Serine (204, } \\
218)\end{array}$ & $6.904 \mathrm{E} 12$ & 2 & $3.452 \mathrm{E} 12$ & .438 & .655 & .068 & .875 & .105 \\
\hline & $\begin{array}{l}\text { L-Threonine (218, } \\
\text { 291) }\end{array}$ & $2.527 \mathrm{E} 11$ & 2 & $1.264 \mathrm{E} 11$ & .955 & .412 & .137 & 1.911 & .178 \\
\hline & beta-Alanine (248) & $5.280 \mathrm{E} 11$ & 2 & $2.640 \mathrm{E} 11$ & 1.304 & .307 & .179 & 2.608 & .229 \\
\hline & $\begin{array}{l}\text { Aspartic acid } \\
(232)\end{array}$ & $3.678 \mathrm{E} 13$ & 2 & $1.839 \mathrm{E} 13$ & .211 & .813 & .034 & .422 & .076 \\
\hline & $\begin{array}{l}\text { 5-oxo-Proline } \\
(156)\end{array}$ & 8.627E13 & 2 & $4.314 \mathrm{E} 13$ & 1.353 & .295 & .184 & 2.705 & .236 \\
\hline & GABA $(304,174)$ & $3.876 \mathrm{E} 15$ & 2 & $1.938 \mathrm{E} 15$ & 1.591 & .244 & .210 & 3.181 & .272 \\
\hline
\end{tabular}




\begin{tabular}{|c|c|c|c|c|c|c|c|c|c|}
\hline & $\begin{array}{l}\text { Glutamic acid } \\
(246)\end{array}$ & $6.407 \mathrm{E} 15$ & 2 & $3.203 \mathrm{E} 15$ & .965 & .409 & .139 & 1.929 & .179 \\
\hline & $\begin{array}{l}\text { L-Phenylalanine } \\
(218,192)\end{array}$ & $3.201 \mathrm{E} 14$ & 2 & $1.601 \mathrm{E} 14$ & 2.316 & .141 & .279 & 4.633 & .379 \\
\hline & $\begin{array}{l}\text { L-Asparagine } \\
(188,231)\end{array}$ & $2.833 \mathrm{E} 16$ & 2 & $1.416 \mathrm{E} 16$ & 1.330 & .301 & .181 & 2.660 & .233 \\
\hline & $\begin{array}{l}\text { cis-Aconitic acid } \\
(229,375)\end{array}$ & 7.924E11 & 2 & $3.962 \mathrm{E} 11$ & 1.514 & .259 & .201 & 3.028 & .260 \\
\hline & Glutamine (156) & $1.839 \mathrm{E} 15$ & 2 & $9.193 \mathrm{E} 14$ & 2.533 & .121 & .297 & 5.066 & .410 \\
\hline & $\begin{array}{l}\text { Isocitric acid } \\
(273)\end{array}$ & $1.072 \mathrm{E} 16$ & 2 & 5.362E15 & .045 & .956 & .007 & .090 & .055 \\
\hline & D-Mannitol 319 & $1.079 \mathrm{E} 15$ & 2 & $5.395 \mathrm{E} 14$ & 11.727 & .002 & .662 & 23.454 & .974 \\
\hline & $\begin{array}{l}\text { Palmitic acid (313, } \\
314)\end{array}$ & $3.431 \mathrm{E} 12$ & 2 & $1.715 \mathrm{E} 12$ & 1.449 & .273 & .194 & 2.897 & .251 \\
\hline & $\begin{array}{l}\text { Galactaric acid } \\
(333)\end{array}$ & $3.436 \mathrm{E} 11$ & 2 & $1.718 \mathrm{E} 11$ & .482 & .629 & .074 & .965 & .111 \\
\hline & $\begin{array}{l}\text { L-Tryptophan } \\
(202)\end{array}$ & $3.087 \mathrm{E} 13$ & 2 & $1.543 \mathrm{E} 13$ & 4.127 & .043 & .408 & 8.254 & .613 \\
\hline & $\begin{array}{l}\text { Stearic acid } \\
(341,117)\end{array}$ & $1.768 \mathrm{E} 12$ & 2 & 8.839E11 & .989 & .400 & .142 & 1.979 & .183 \\
\hline & $\begin{array}{l}\text { Glucose-6-phosph } \\
\text { ate ( } 387)\end{array}$ & $1.653 \mathrm{E} 12$ & 2 & $8.266 \mathrm{E} 11$ & .376 & .694 & .059 & .752 & .097 \\
\hline & Raffinose (437) & $2.208 \mathrm{E} 11$ & 2 & $1.104 \mathrm{E} 11$ & .144 & .867 & .023 & .289 & .067 \\
\hline & Galactinol (204) & $8.743 \mathrm{E} 13$ & 2 & $4.371 \mathrm{E} 13$ & 1.141 & .352 & .160 & 2.281 & .205 \\
\hline Genoty & & & & & & & & & \\
\hline Stress & $\begin{array}{l}\text { Fructose }(217, \\
307)\end{array}$ & $1.393 \mathrm{E} 14$ & 2 & $6.965 \mathrm{E} 13$ & 1.306 & .307 & .179 & 2.611 & .229 \\
\hline & Mannose & $8.052 \mathrm{E} 12$ & 2 & $4.026 \mathrm{E} 12$ & .375 & .695 & .059 & .750 & .097 \\
\hline & Galactose & $3.162 \mathrm{E} 16$ & 2 & $1.581 \mathrm{E} 16$ & .610 & .560 & .092 & 1.219 & .129 \\
\hline & Glucose & $2.607 \mathrm{E} 15$ & 2 & 1.303E15 & 1.647 & .233 & .215 & 3.294 & .280 \\
\hline & Sorbitol & $3.716 \mathrm{E} 14$ & 2 & $1.858 \mathrm{E} 14$ & 2.788 & .101 & .317 & 5.577 & .446 \\
\hline & Inositol & $3.197 \mathrm{E} 17$ & 2 & $1.598 \mathrm{E} 17$ & 1.550 & .252 & .205 & 3.100 & .266 \\
\hline & Sucrose & 5.927E15 & 2 & $2.964 \mathrm{E} 15$ & .009 & .991 & .001 & .017 & .051 \\
\hline & Maltose & $2.233 \mathrm{E} 12$ & 2 & $1.117 \mathrm{E} 12$ & .923 & .424 & .133 & 1.846 & .173 \\
\hline & L-Isoleucine (158) & $9.373 \mathrm{E} 13$ & 2 & $4.687 \mathrm{E} 13$ & 1.378 & .289 & .187 & 2.757 & .240 \\
\hline & L-Proline (142) & $4.012 \mathrm{E} 16$ & 2 & $2.006 \mathrm{E} 16$ & 1.407 & .282 & .190 & 2.815 & .245 \\
\hline & Glycine (174) & $9.490 \mathrm{E} 12$ & 2 & $4.745 \mathrm{E} 12$ & 1.310 & .306 & .179 & 2.619 & .230 \\
\hline & $\begin{array}{l}\text { Glyceric acid } \\
(189,292)\end{array}$ & 4.341E9 & 2 & $2.171 \mathrm{E} 9$ & 1.000 & .396 & .143 & 2.000 & .184 \\
\hline & $\begin{array}{l}\text { Fumaric acid } \\
(245)\end{array}$ & $7.130 \mathrm{E} 9$ & 2 & $3.565 \mathrm{E} 9$ & .017 & .983 & .003 & .034 & .052 \\
\hline & $\begin{array}{l}\text { L-Serine }(204, \\
218)\end{array}$ & $1.836 \mathrm{E} 13$ & 2 & $9.178 \mathrm{E} 12$ & 1.163 & .345 & .162 & 2.327 & .208 \\
\hline & $\begin{array}{l}\text { L-Threonine (218, } \\
\text { 291) }\end{array}$ & $2.500 \mathrm{E} 11$ & 2 & $1.250 \mathrm{E} 11$ & .945 & .416 & .136 & 1.890 & .176 \\
\hline & beta-Alanine (248) & $9.419 \mathrm{E} 11$ & 2 & 4.709E11 & 2.326 & .140 & .279 & 4.652 & .380 \\
\hline
\end{tabular}




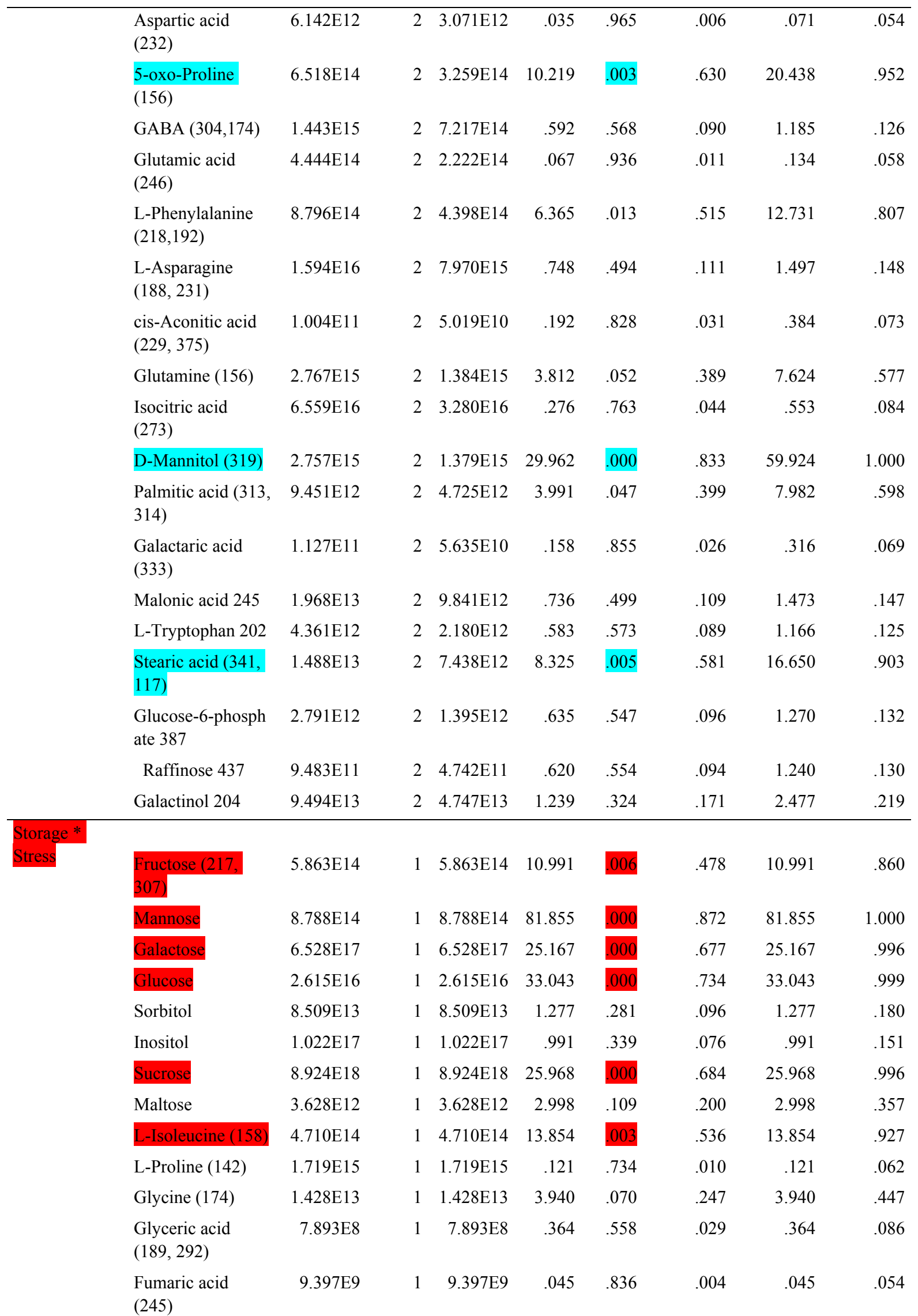




\begin{tabular}{|c|c|c|c|c|c|c|c|c|c|}
\hline & $\begin{array}{l}\text { L-Serine (204, } \\
218)\end{array}$ & $2.198 \mathrm{E} 13$ & 1 & $2.198 \mathrm{E} 13$ & 2.787 & .121 & .188 & 2.787 & .336 \\
\hline & $\begin{array}{l}\text { L-Threonine (218, } \\
\text { 291) }\end{array}$ & $6.183 \mathrm{E} 11$ & 1 & $6.183 \mathrm{E} 11$ & 4.675 & .052 & .280 & 4.675 & .511 \\
\hline & beta-Alanine (248) & $4.666 \mathrm{E} 10$ & 1 & $4.666 \mathrm{E} 10$ & .230 & .640 & .019 & .230 & .073 \\
\hline & $\begin{array}{l}\text { Aspartic acid } \\
(232)\end{array}$ & $2.556 \mathrm{E} 14$ & 1 & $2.556 \mathrm{E} 14$ & 2.936 & .112 & .197 & 2.936 & .351 \\
\hline & $\begin{array}{l}\text { 5-oxo-Proline } \\
(156)\end{array}$ & $2.859 \mathrm{E} 14$ & 1 & $2.859 \mathrm{E} 14$ & 8.963 & .011 & .428 & 8.963 & .785 \\
\hline & GABA $(304,174)$ & $3.722 \mathrm{E} 15$ & 1 & $3.722 \mathrm{E} 15$ & 3.055 & .106 & .203 & 3.055 & .363 \\
\hline & Glutamic acid 246 & $1.186 \mathrm{E} 15$ & 1 & $1.186 \mathrm{E} 15$ & .357 & .561 & .029 & .357 & .085 \\
\hline & $\begin{array}{l}\text { L-Phenylalanine } \\
(218,192)\end{array}$ & $2.639 \mathrm{E} 15$ & 1 & $2.639 \mathrm{E} 15$ & 38.198 & .000 & .761 & 38.198 & 1.000 \\
\hline & $\begin{array}{l}\text { L-Asparagine } \\
(188,231)\end{array}$ & $1.470 \mathrm{E} 16$ & 1 & $1.470 \mathrm{E} 16$ & 1.380 & .263 & .103 & 1.380 & .191 \\
\hline & $\begin{array}{l}\text { cis-Aconitic acid } \\
(229,375)\end{array}$ & $2.219 \mathrm{E} 10$ & 1 & $2.219 \mathrm{E} 10$ & .085 & .776 & .007 & .085 & .058 \\
\hline & Glutamine (156) & $1.091 \mathrm{E} 14$ & 1 & $1.091 \mathrm{E} 14$ & .301 & .594 & .024 & .301 & .080 \\
\hline & $\begin{array}{l}\text { Isocitric acid } \\
(273)\end{array}$ & $3.715 \mathrm{E} 16$ & 1 & $3.715 \mathrm{E} 16$ & .313 & .586 & .025 & .313 & .081 \\
\hline & D-Mannitol (319) & $4.370 \mathrm{E} 14$ & 1 & $4.370 \mathrm{E} 14$ & 9.499 & .010 & .442 & 9.499 & .807 \\
\hline & $\begin{array}{l}\text { Palmitic acid (313, } \\
314)\end{array}$ & $3.620 \mathrm{E} 12$ & 1 & $3.620 \mathrm{E} 12$ & 3.057 & .106 & .203 & 3.057 & .363 \\
\hline & $\begin{array}{l}\text { Galactaric acid } \\
(333)\end{array}$ & $1.374 \mathrm{E} 12$ & 1 & $1.374 \mathrm{E} 12$ & 3.857 & .073 & .243 & 3.857 & .439 \\
\hline & $\begin{array}{l}\text { L-Tryptophan } \\
(202)\end{array}$ & $3.381 \mathrm{E} 13$ & 1 & $3.381 \mathrm{E} 13$ & 9.041 & .011 & .430 & 9.041 & .788 \\
\hline & $\begin{array}{l}\text { Stearic acid } \\
(341,117)\end{array}$ & $9.122 \mathrm{E} 12$ & 1 & $9.122 \mathrm{E} 12$ & 10.211 & .008 & .460 & 10.211 & .834 \\
\hline & $\begin{array}{l}\text { Glucose-6-phosph } \\
\text { ate }(387)\end{array}$ & $5.440 \mathrm{E} 12$ & 1 & $5.440 \mathrm{E} 12$ & 2.475 & .142 & .171 & 2.475 & .305 \\
\hline & Raffinose (437) & $1.752 \mathrm{E} 12$ & 1 & $1.752 \mathrm{E} 12$ & 2.290 & .156 & .160 & 2.290 & .286 \\
\hline & Galactinol (204) & $3.235 \mathrm{E} 14$ & 1 & $3.235 \mathrm{E} 14$ & 8.440 & .013 & .413 & 8.440 & .760 \\
\hline $\begin{array}{l}\text { Genotype } \\
\text { Storage* } \\
\text { Stress }\end{array}$ & $\begin{array}{l}\text { Fructose }(217, \\
307)\end{array}$ & 2.307E14 & 2 & $1.154 \mathrm{E} 14$ & 2.163 & .158 & .265 & 4.326 & .357 \\
\hline & Mannose & $1.642 \mathrm{E} 13$ & 2 & $8.212 \mathrm{E} 12$ & .765 & .487 & .113 & 1.530 & .151 \\
\hline & Galactose & $1.701 \mathrm{E} 16$ & 2 & $8.506 \mathrm{E} 15$ & .328 & .727 & .052 & .656 & .091 \\
\hline & Glucose & $3.727 \mathrm{E} 14$ & 2 & $1.864 \mathrm{E} 14$ & .235 & .794 & .038 & .471 & .079 \\
\hline & Sorbitol & $4.110 \mathrm{E} 14$ & 2 & $2.055 \mathrm{E} 14$ & 3.085 & .083 & .340 & 6.169 & .486 \\
\hline & Inositol & $2.091 \mathrm{E} 17$ & 2 & $1.045 \mathrm{E} 17$ & 1.014 & .392 & .145 & 2.028 & .186 \\
\hline & Sucrose & $3.293 \mathrm{E} 16$ & 2 & $1.646 \mathrm{E} 16$ & .048 & .953 & .008 & .096 & .056 \\
\hline & Maltose & $4.586 \mathrm{E} 11$ & 2 & $2.293 \mathrm{E} 11$ & .189 & .830 & .031 & .379 & .073 \\
\hline & L-Isoleucine (158) & $4.431 \mathrm{E} 13$ & 2 & $2.215 \mathrm{E} 13$ & .652 & .539 & .098 & 1.303 & .135 \\
\hline & L-Proline (142) & $1.251 \mathrm{E} 16$ & 2 & $6.254 \mathrm{E} 15$ & .439 & .655 & .068 & .877 & .105 \\
\hline & Glycine (174) & $1.166 \mathrm{E} 13$ & 2 & $5.828 \mathrm{E} 12$ & 1.608 & .241 & .211 & 3.217 & .274 \\
\hline
\end{tabular}




\begin{tabular}{|c|c|c|c|c|c|c|c|c|}
\hline $\begin{array}{l}\text { Glyceric acid } \\
(189,292)\end{array}$ & $3.535 \mathrm{E} 9$ & 2 & $1.767 \mathrm{E} 9$ & .814 & .466 & .120 & 1.629 & .158 \\
\hline $\begin{array}{l}\text { Fumaric acid } \\
(245)\end{array}$ & 4.609E11 & 2 & $2.305 \mathrm{E} 11$ & 1.103 & .363 & .155 & 2.206 & .199 \\
\hline $\begin{array}{l}\text { L-Serine (204, } \\
218)\end{array}$ & $2.060 \mathrm{E} 13$ & 2 & $1.030 \mathrm{E} 13$ & 1.306 & .307 & .179 & 2.612 & .229 \\
\hline $\begin{array}{l}\text { L-Threonine (218, } \\
\text { 291) }\end{array}$ & $1.709 \mathrm{E} 11$ & 2 & 8.543E10 & .646 & .541 & .097 & 1.292 & .134 \\
\hline beta-Alanine (248) & $2.379 \mathrm{E} 11$ & 2 & $1.190 \mathrm{E} 11$ & .588 & .571 & .089 & 1.175 & .126 \\
\hline $\begin{array}{l}\text { Aspartic acid } \\
(232)\end{array}$ & $4.206 \mathrm{E} 13$ & 2 & $2.103 \mathrm{E} 13$ & .242 & .789 & .039 & .483 & .080 \\
\hline $\begin{array}{l}\text { 5-oxo-Proline } \\
(156)\end{array}$ & $4.363 \mathrm{E} 13$ & 2 & $2.181 \mathrm{E} 13$ & .684 & .523 & .102 & 1.368 & .139 \\
\hline GABA $(304,174)$ & $8.965 \mathrm{E} 15$ & 2 & $4.483 \mathrm{E} 15$ & 3.680 & .057 & .380 & 7.359 & .561 \\
\hline $\begin{array}{l}\text { Glutamic acid } \\
(246)\end{array}$ & $2.047 \mathrm{E} 14$ & 2 & $1.024 \mathrm{E} 14$ & .031 & .970 & .005 & .062 & .054 \\
\hline $\begin{array}{l}\text { L-Phenylalanine } \\
(218,192)\end{array}$ & $1.225 \mathrm{E} 14$ & 2 & $6.126 \mathrm{E} 13$ & .887 & .437 & .129 & 1.773 & .168 \\
\hline $\begin{array}{l}\text { L-Asparagine } \\
(188,231)\end{array}$ & $3.210 \mathrm{E} 16$ & 2 & $1.605 \mathrm{E} 16$ & 1.507 & .261 & .201 & 3.013 & .259 \\
\hline $\begin{array}{l}\text { cis-Aconitic acid } \\
(229,375)\end{array}$ & $1.399 \mathrm{E} 11$ & 2 & $6.994 \mathrm{E} 10$ & .267 & .770 & .043 & .535 & .083 \\
\hline Glutamine (156) & $2.676 \mathrm{E} 15$ & 2 & $1.338 \mathrm{E} 15$ & 3.687 & .056 & .381 & 7.374 & .562 \\
\hline $\begin{array}{l}\text { Isocitric acid } \\
(273)\end{array}$ & $2.174 \mathrm{E} 16$ & 2 & $1.087 \mathrm{E} 16$ & .092 & .913 & .015 & .183 & .061 \\
\hline D-Mannitol (319) & $1.608 \mathrm{E} 15$ & 2 & $8.039 \mathrm{E} 14$ & 17.473 & .000 & .744 & 34.946 & .998 \\
\hline $\begin{array}{l}\text { Palmitic acid ( } 313 \text {, } \\
314)\end{array}$ & $3.140 \mathrm{E} 11$ & 2 & $1.570 \mathrm{E} 11$ & .133 & .877 & .022 & .265 & .066 \\
\hline $\begin{array}{l}\text { Galactaric acid } \\
(333)\end{array}$ & $3.418 \mathrm{E} 11$ & 2 & $1.709 \mathrm{E} 11$ & .480 & .630 & .074 & .960 & .111 \\
\hline $\begin{array}{l}\text { L-Tryptophan } \\
\text { (202) }\end{array}$ & 5.857E12 & 2 & $2.928 \mathrm{E} 12$ & .783 & .479 & .115 & 1.566 & .153 \\
\hline $\begin{array}{l}\text { Stearic acid } \\
(341,117)\end{array}$ & $2.456 \mathrm{E} 11$ & 2 & $1.228 \mathrm{E} 11$ & .137 & .873 & .022 & .275 & .067 \\
\hline $\begin{array}{l}\text { Glucose- } 6 \text {-phosph } \\
\text { ate }(387)\end{array}$ & $9.204 \mathrm{E} 9$ & 2 & 4.602E9 & .002 & .998 & .000 & .004 & .050 \\
\hline Raffinose (437) & $1.087 \mathrm{E} 12$ & 2 & $5.433 \mathrm{E} 11$ & .710 & .511 & .106 & 1.420 & .143 \\
\hline Galactinol (204) & $3.187 \mathrm{E} 13$ & 2 & $1.593 \mathrm{E} 13$ & .416 & .669 & .065 & .832 & .102 \\
\hline
\end{tabular}


Table S2. Significant differnces $(\mathrm{P}<0.05)$ are highlighted by colours

\section{Tests of Between-Subjects Effects}

\begin{tabular}{|c|c|c|c|c|c|c|c|c|c|}
\hline Source & $\begin{array}{l}\text { Dependent } \\
\text { Variable }\end{array}$ & $\begin{array}{c}\text { Type III Sum } \\
\text { of Squares }\end{array}$ & $\mathrm{df}$ & $\begin{array}{c}\text { Mean } \\
\text { Square }\end{array}$ & $\mathrm{F}$ & Sig. & $\begin{array}{c}\text { Partial } \\
\text { Eta } \\
\text { Squared } \\
\end{array}$ & $\begin{array}{l}\text { Noncent. } \\
\text { Parameter }\end{array}$ & $\begin{array}{c}\text { Observed } \\
\text { Power }^{\mathrm{b}}\end{array}$ \\
\hline Corrected & SA & $2997.663^{\mathrm{a}}$ & 11 & 272.515 & 3.907 & .014 & .782 & 42.979 & .906 \\
\hline \multirow[t]{4}{*}{ Model } & IAA & $407.497^{\mathrm{c}}$ & 11 & 37.045 & 1.694 & .189 & .608 & 18.638 & .509 \\
\hline & $\mathrm{ABA}$ & $220760.507^{\mathrm{d}}$ & 11 & 20069.137 & 12.614 & .000 & .920 & 138.759 & 1.000 \\
\hline & $\mathrm{JA}$ & $165.977^{\mathrm{e}}$ & 11 & 15.089 & 1.483 & .254 & .576 & 16.309 & .448 \\
\hline & JA-ILE & $6.059^{\mathrm{f}}$ & 11 & .551 & 3.276 & .026 & .750 & 36.035 & .839 \\
\hline \multirow[t]{8}{*}{ Intercept } & SA & 45948.117 & 1 & 45948.117 & 658.77 & .000 & .982 & 658.775 & 1.000 \\
\hline & & & & & 5 & & & & \\
\hline & IAA & 5716.681 & 1 & 5716.681 & 261.46 & .000 & .956 & 261.468 & 1.000 \\
\hline & & & & & 8 & & & & \\
\hline & $\mathrm{ABA}$ & 1066412.740 & 1 & 1066412.74 & 670.29 & .000 & .982 & 670.292 & 1.000 \\
\hline & & & & 0 & 2 & & & & \\
\hline & $\mathrm{JA}$ & 195.684 & 1 & 195.684 & 19.228 & .001 & .616 & 19.228 & .980 \\
\hline & JA-ILE & 4.808 & 1 & 4.808 & 28.591 & .000 & .704 & 28.591 & .998 \\
\hline \multirow[t]{5}{*}{ Genotype } & SA & 472.494 & 2 & 236.247 & 3.387 & .068 & .361 & 6.774 & .525 \\
\hline & IAA & 200.193 & 2 & 100.096 & 4.578 & .033 & .433 & 9.156 & .661 \\
\hline & $\mathrm{ABA}$ & 4600.755 & 2 & 2300.377 & 1.446 & .274 & .194 & 2.892 & .250 \\
\hline & JA & 35.494 & 2 & 17.747 & 1.744 & .216 & .225 & 3.488 & .295 \\
\hline & JA-ILE & .424 & 2 & .212 & 1.261 & .318 & .174 & 2.521 & .223 \\
\hline \multirow[t]{5}{*}{ Stress } & SA & 349.549 & 1 & 349.549 & 5.012 & .045 & .295 & 5.012 & .539 \\
\hline & IAA & 3.015 & 1 & 3.015 & .138 & .717 & .011 & .138 & .064 \\
\hline & $\mathrm{ABA}$ & 69711.671 & 1 & 69711.671 & 43.817 & .000 & .785 & 43.817 & 1.000 \\
\hline & JA & .872 & 1 & .872 & .086 & .775 & .007 & .086 & .058 \\
\hline & JA-ILE & .275 & 1 & .275 & 1.636 & .225 & .120 & 1.636 & .218 \\
\hline \multirow[t]{5}{*}{ Storage } & SA & 1001.729 & 1 & 1001.729 & 14.362 & .003 & .545 & 14.362 & .935 \\
\hline & IAA & 35.316 & 1 & 35.316 & 1.615 & .228 & .119 & 1.615 & .216 \\
\hline & $\mathrm{ABA}$ & 108934.442 & 1 & 108934.442 & 68.471 & .000 & .851 & 68.471 & 1.000 \\
\hline & JA & 71.775 & 1 & 71.775 & 7.053 & .021 & .370 & 7.053 & .684 \\
\hline & JA-ILE & 3.390 & 1 & 3.390 & 20.162 & .001 & .627 & 20.162 & .984 \\
\hline Genotype * & SA & 20.883 & 2 & 10.441 & .150 & .863 & .024 & .299 & .068 \\
\hline \multirow[t]{4}{*}{ Stress } & IAA & 34.035 & 2 & 17.018 & .778 & .481 & .115 & 1.557 & .152 \\
\hline & $\mathrm{ABA}$ & 2332.282 & 2 & 1166.141 & .733 & .501 & .109 & 1.466 & .146 \\
\hline & JA & .187 & 2 & .094 & .009 & .991 & .002 & .018 & .051 \\
\hline & JA-ILE & .355 & 2 & .178 & 1.056 & .378 & .150 & 2.112 & .193 \\
\hline Genotype * & $\mathrm{SA}$ & 79.406 & 2 & 39.703 & .569 & .581 & .087 & 1.138 & .123 \\
\hline \multirow[t]{2}{*}{ Storage } & IAA & 57.848 & 2 & 28.924 & 1.323 & .303 & .181 & 2.646 & .232 \\
\hline & $\mathrm{ABA}$ & 3452.445 & 2 & 1726.222 & 1.085 & .369 & .153 & 2.170 & .197 \\
\hline
\end{tabular}




\begin{tabular}{llrrrrrrrr}
\hline & JA & 10.447 & 2 & 5.224 & .513 & .611 & .079 & 1.027 & .116 \\
& JA-ILE & .562 & 2 & .281 & 1.671 & .229 & .218 & 3.342 & .284 \\
\hline Stress * & SA & 806.966 & 1 & 806.966 & 11.570 & .005 & .491 & 11.570 & .877 \\
Storage & IAA & 72.296 & 1 & 72.296 & 3.307 & .094 & .216 & 3.307 & .387 \\
& ABA & 30576.610 & 1 & 30576.610 & 19.219 & .001 & .616 & 19.219 & .980 \\
& JA & 9.547 & 1 & 9.547 & .938 & .352 & .073 & .938 & .145 \\
& JA-ILE & .562 & 1 & .562 & 3.342 & .092 & .218 & 3.342 & .391 \\
\hline Genotype * & SA & 266.636 & 2 & 133.318 & 1.911 & .190 & .242 & 3.823 & .320 \\
Stress * & IAA & 4.793 & 2 & 2.397 & .110 & .897 & .018 & .219 & .063 \\
Storage & ABA & 1152.304 & 2 & 576.152 & .362 & .704 & .057 & .724 & .095 \\
& JA & 37.655 & 2 & 18.828 & 1.850 & .199 & .236 & 3.700 & .310 \\
& JA-ILE & .491 & 2 & .245 & 1.460 & .271 & .196 & 2.919 & .252 \\
\hline
\end{tabular}

\section{Copyrights}

Copyright for this article is retained by the author(s), with first publication rights granted to the journal.

This is an open-access article distributed under the terms and conditions of the Creative Commons Attribution license (http://creativecommons.org/licenses/by/3.0/). 